\title{
Role of Hydraulic Conductivity on Surface and Groundwater Interaction in Wetlands
}

\author{
Cevza Melek Kazezyılmaz-Alhan \\ Istanbul University, Civil Engineering Department \\ Turkey
}

\section{Introduction}

There has been a growing interest in understanding the mechanisms involved in surface and groundwater interactions since these interactions play a crucial role in the behavior of hydrology and contaminant transport in streams, lakes, wetlands, and groundwater (Hakenkamp et al, 1993; Winter, 1995; Packman \& Bencala, 2000; Bencala, 2000; Medina et al, 2002). Wetlands are an important part of water resources since they control peak flow of surface runoff and clean polluted water as downstream receiving water bodies and therefore have been recognized as one of the best management practices (Mitsch \& Gosselink, 2000; Moore et al., 2002; Mitchell et al., 2002). Wetlands are located in transitional zones between uplands and downstream flooded systems. Surface and groundwater interactions, which occur in these critical zones, result in a change in surface and groundwater depth. Moreover, pollutants in either surface water or groundwater are mixed and the quality of both sources is affected by each other. Therefore, it is important to understand the role of surface and groundwater interactions on wetland sites and incorporate them into the wetland models in order to obtain accurate solutions.

The definition of a wetland is difficult since there is no definite boundary for wetlands over the landscape and wetland characteristics change. Different definitions have resulted from government agencies that take either legal or ecological criteria as a basis for wetlands within their jurisdiction. In Section 404 of the Clean Water Act of Environmental Protection Agency (EPA), wetlands are defined as "areas that are inundated or saturated by surface or groundwater at a frequency and duration sufficient to support a prevalence of vegetation typically adapted for life in saturated soil conditions". From a hydrologic point of view, the change of surface water level or subsurface water table level through time is important. Usually, areas where the depth of standing water is less than $2 \mathrm{~m}$ are considered as wetlands. The amount of water present in wetlands is important to support water supply and water quality. It also affects the type of animals and plants living in these areas. Wetlands are classified according to their ecological and hydrological similarities (Mitsch \& Gosselink, 2000).

The type of interaction between groundwater and wetlands depends on the geomorphological location of the wetland. Wetlands gain water if they are located on seepage faces where there is an abrupt change in landscape slope (Figure 1A), or if there is a stream near the wetland location (Figure 1B). Water level in wetlands is changed usually by direct precipitation or runoff. Especially in riverine wetlands, water level changes 
periodically and very often, since its source comes from rivers. Due to this fact, this type of wetland has more complex interactions which affect its hydraulic/hydrologic characteristics. The water and chemical balances determine the principal characteristics and functions of wetlands. Wetlands are very sensitive to changing hydrological conditions. Since interactions between wetland and groundwater affect the water and chemical balances, it is important to include these interactions into the wetland models.

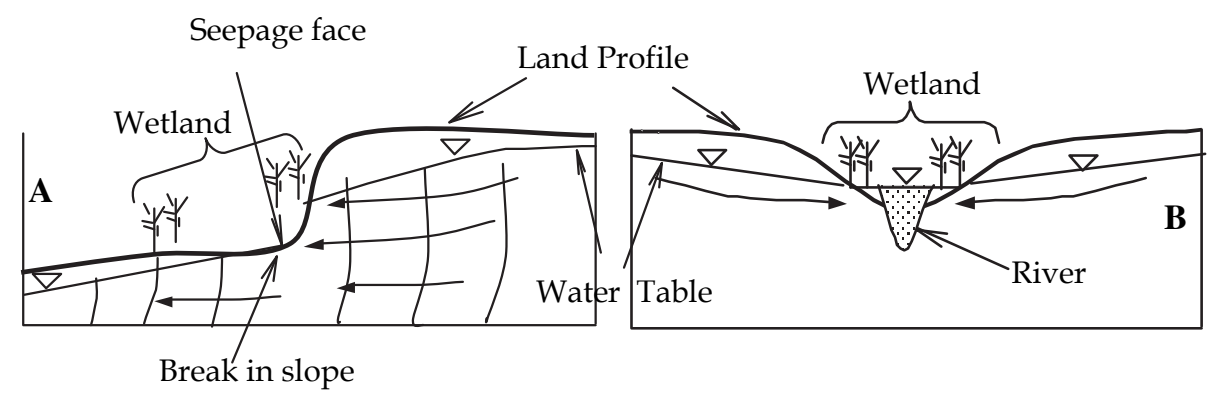

Fig. 1. Wetland and groundwater interactions: (A) Inflow from seepage faces and break in slope of water table. (B) Inflow to streams. (modified after Winter et al., 1998)

There have been previous studies reported in the literature that investigate various aspects of surface and groundwater interactions in wetlands. The importance of modeling interactions between groundwater and wetlands and their effect on wetland functions are discussed in detail by Winter et al. (1998), Winter (1999), and Price \& Wadington (2000). Experiments are conducted in order to observe the effect of surface and groundwater interactions on wetland hydrology and contaminant transport at different wetland sites (Winter \& Rosenberry, 1995; Devito \& Hill, 1997; Choi \& Harvey, 2000; McHale et al 2004). In addition to these studies, many researchers worked on developing numerical models of wetland hydrology and wetland water quality incorporating surface and groundwater interactions (Restrepo et al., 1998; Krasnostein \& Oldham, 2004; Keefe et al., 2004; Crowe et al., 2004; Kazezyılmaz-Alhan et al., 2007).

Examples of recent studies include Harvey et al (2006) who modeled interactions between surface water and groundwater in the wetland area located in central Everglades, Florida, USA in order to quantify recharge and discharge in the basin's vast interior areas. Kazezyılmaz-Alhan \& Medina (2008) discussed the effect of surface and groundwater interactions on wetland sites with different characteristics. He et al (2008) developed a coupled finite volume model by using depth averaged two dimensional surface flow and three dimensional subsurface flow for wetlands incorporating surface-subsurface Water ${ }^{-}$Resources Investigations, Book 6, Chap A1, U.S. Geological Survey.

McHale, M.R.; Cirmo, C.P.; Mitchell, M.J. \& McDonnell, J.J. (2004). Wetland Nitrogen Dynamics in an Adirondack Forested Watershed. Hydrological Processerical model of subsurface vertical flow constructed wetlands called as FITOVERT. Min \& Wise (2010) developed a two-dimensional hydrodynamic and solute transport modeling of a largescaled, subtropical, free water surface constructed wetland in the Everglades of Florida, LiSthis chapter, the role of hydraulic conductivity on surface and groundwater interactions in wetlands is discussed. Both wetland hydrology and wetland water quality are 
investigated and particularly, the behavior of surface water and groundwater depths and the flux between surface water and groundwater are observed. For this purpose, several models are employed which incorporate surface and groundwater interactions and handle the interactions from different points of view. Among these models are WETland Solute TrANsport Dynamics (WETSAND), Visual MODular Finite-Difference FLOW model (MODFLOW) and EPA Storm Water Management Model (SWMM). WETSAND is a wetland model which has both surface flow and solute transport components, and accounts for upstream contributions from urbanized areas. Visual MODFLOW is a three-dimensional groundwater flow and contaminant transport simulation model. EPA SWMM is a dynamic rainfall-runoff model and calculates surface runoff, channel flow, groundwater flow and depth in aquifer underlying each subcatchment, and water quality. Applications are presented by simulating a conceptual wetland-aquifer system with Visual MODFLOW, the Duke University restored wetland site in the Sandy Creek watershed of Durham, North Carolina in USA with WETSAND and Büyükçekmece wetland site located around Büyükçekmece Lake in Istanbul, Turkey with EPA SWMM.

\section{Numerical modelling}

This section discusses three numerical models on surface water and groundwater hydrology and contaminant transport. The common point of these models is incorporating surface and groundwater interactions but each model approaches the mechanism and the consequence of these interactions from a different point of view.

\subsection{WETland Solute TrANsport Dynamics (WETSAND)}

WETland Solute TrANsport Dynamics (WETSAND) is a general comprehensive dynamic wetland model developed by Kazezyılmaz-Alhan et al (2007) which has both water quantity and water quality components, and incorporates the effects of surface and groundwater interactions. While the water quantity component computes water level and velocity distribution as a function of time and space, the water quality component computes Phosphorus and Nitrogen compounds also as a function of time and space. WETSAND also takes into account the effect of flow generated from upstream areas. Figure 2 shows the graphical representation of the conceptual wetland model. During a storm event, overland flow develops on urbanized areas and flows into the wetland area and streams located downstream of the watershed. Overland flow washes off the pollutants which build up on the surface during dry days and these pollutants also reach the wetland site with the overland flow. Besides the overland flow, rainfall and groundwater discharge also contribute to the surface water of the wetland site. Evapotranspiration, infiltration, and groundwater recharge are the water sink terms of the wetland site.

\subsubsection{Wetland hydrology}

The surface water depth, velocity, and flow through the wetland area are calculated by the diffusion wave equation that applies to the milder slopes (\% 0.1 to $\% 0.01)$ which is the case in wetlands. The one-dimensional diffusion wave equation is given as follows:

$$
\frac{\partial y}{\partial t}+c \frac{\partial y}{\partial x}=K_{1} \frac{\partial^{2} y}{\partial x^{2}}+\bar{q}
$$




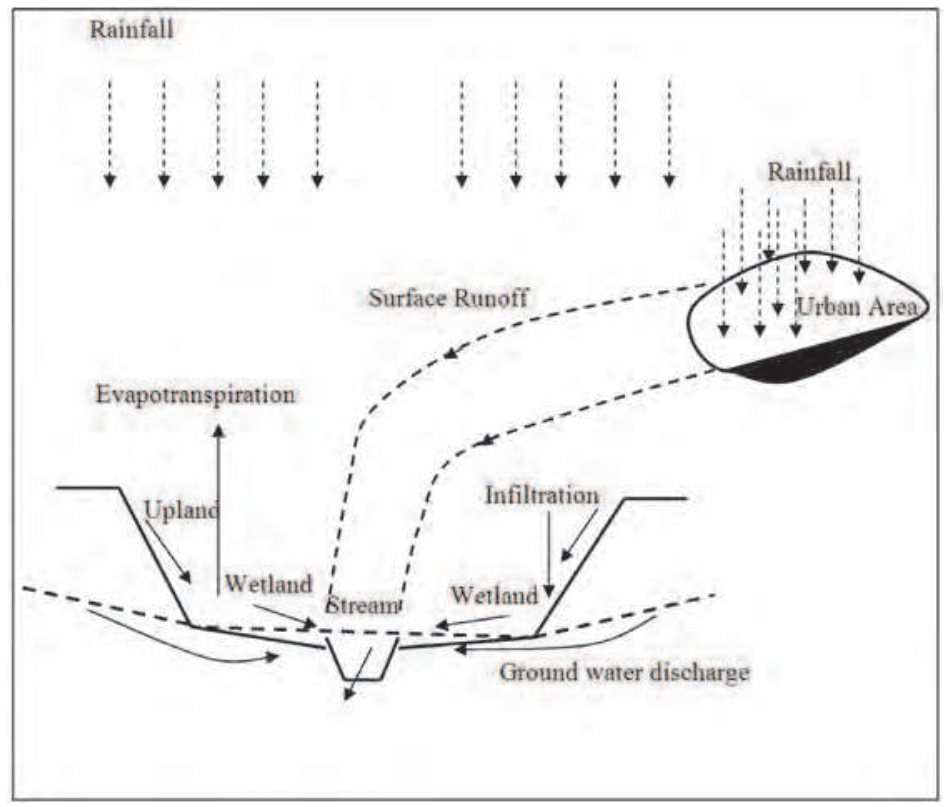

Fig. 2. Schematic of the WETSAND model (Kazezyılmaz-Alhan et al, 2007).

$$
\bar{q}=q_{r}-q_{\mathrm{inf}}-q_{e t}+q_{d r c h}+q_{l} \quad c=m V \quad K_{1}=\frac{V y}{2 S_{0}}
$$

where $y$ is the surface water depth $(L), t$ is time $(T), x$ is the distance $(L), c$ is the wave celerity $(L / T), K_{1}$ is the hydraulic diffusivity $\left(L^{2} / T\right), \bar{q}$ is the water source/sink term $(L / T), V$ is the water velocity $(L / T), S_{0}$ is the bottom slope $(L / L)$ and $m$ is given according to the flow rate-friction slope relationship (Ponce, 1989). While rainfall $\left(q_{r}\right)$, groundwater discharge $\left(q_{d r c h}\right)$, and lateral inflow $\left(q_{l}\right)$ occupy as water source terms; infiltration $\left(q_{\text {inf }}\right)$, evapotranspiration $\left(q_{e t}\right)$, and groundwater recharge $\left(q_{d r c h}\right)$ occupy as water sink terms in the term $q$. Infiltration is calculated by the modified version of the Green-Ampt method during unsteady rainfall (Chu, 1978) and evapotranspiration is calculated by the Thornthwaite (1948) method. The groundwater recharge and groundwater discharge terms represent surface and groundwater interaction at the wetland site and are calculated by using the Darcy's Law as follows:

$$
q_{\text {drch }}=-K_{x} \frac{\partial H}{\partial x} \begin{cases}<0 & \text { groundwater recharge } \\ >0 & \text { groundwater discharge }\end{cases}
$$

where $H$ is total head $(L)$, and $K_{x}$ is the horizontal hydraulic conductivity $(L / T)$. The exchange between surface water and groundwater is calculated in the lateral direction at the banks of the wetland. Overland flow generated over both upland and wetland sites becomes the lateral inflow of the stream. The flow on the wetland site is calculated by the power law for velocity in terms of depth and the friction slope (Kadlec, 1990). This law employs both the effect of a vertical vegetation stem density gradient and a bottom-elevation distribution. The flow rate on a wetland site is given by (Kadlec and Knight, 1996): 


$$
Q= \begin{cases}K_{\mathrm{d}} W y^{3} S_{0} & \text { dense vegetation } \\ K_{\mathrm{s}} W y^{3} S_{0} & \text { sparse vegetation }\end{cases}
$$

where $Q$ is the flow rate in ( $\mathrm{m}^{3} /$ day), $W$ is the wetland width $(L)$, and $K_{d}$ and $K_{s}$ are the coefficients which reflect the vegetation density with $K_{d}=1 \times 10^{7} \mathrm{~m}^{-1} \mathrm{day}^{-1}$ and $K_{s}=5 \times 10^{7}$ $\mathrm{m}^{-1}$ day $^{-1}$. In diffusion wave theory, the term $S_{0}$ is replaced by $\left(S_{0}-\partial y / \partial x\right)$. Therefore, the surface water velocity $V$ on a wetland with a cross-sectional area $A=W y$ is calculated using both the continuity $Q=V A$ and Equation (3) as follows:

$$
V=\left\{\begin{array}{l}
K_{d} y^{2}\left(S_{0}-\partial y / \partial x\right) \\
K_{s} y^{2}\left(S_{0}-\partial y / \partial x\right)
\end{array}\right.
$$

The upper boundary condition of the stream flowing through the wetland site is defined as the upstream surface runoff flowing from urbanized areas and the flow rate in the stream is calculated by using the diffusion wave equation as follows:

$$
\frac{\partial Q}{\partial t}+c \frac{\partial Q}{\partial x}=K_{1} \frac{\partial^{2} Q}{\partial x^{2}} \quad c=m V \quad K_{1}=\frac{Q}{2 B S_{0}}
$$

where $B$ is the channel width $(L)$ and $c$ and $K_{1}$ are the wave celerity $(L / T)$ and the hydraulic diffusivity $\left(L^{2} / T\right)$ in stream, respectively.

\subsubsection{Wetland water quality}

The water quality component of the WETSAND model calculates the concentration distribution of both total Nitrogen and total Phosphorus through the wetland and along the stream. WETSAND has also the capability to calculate each compound of nitrogen, namely, organic nitrogen, ammonium nitrogen, and nitrate nitrogen, individually. For each constituent, one dimensional advection-dispersion-reaction equation is solved. The equations for nitrogen compounds are coupled through the first order loss rate constants $K_{O N}$ and $K_{A N}$, which represent ammonification of organic nitrogen into ammonium and nitrification of ammonium into nitrate, respectively. The equations also take into account the vegetation effect of a wetland site represented by plant uptake/release terms as sources and sinks. Finally, the influence of surface and groundwater interactions on contaminant transport is incorporated via the mass flux terms that represent the incoming/outgoing mass due to groundwater recharge/discharge. The surface water velocity in the wetland calculated by the hydrology component of WETSAND is used in the advection term of concentration equations. The concentration formulations of WETSAND are given as follows: Total Phosphorus (TP):

$$
\frac{\partial C_{T P}}{\partial t}=-V \frac{\partial C_{T P}}{\partial x}+\frac{1}{A_{x}} \frac{\partial}{\partial x}\left(A_{x} D_{x} \frac{\partial C_{T P}}{\partial x}\right)+\frac{q_{L i n}}{A_{x}}\left(C_{T P}^{L}-C_{T P}\right)+\frac{q_{g w d}}{A_{x}}\left(C_{T P}^{g w}-C_{T P}\right)-K_{T P} C_{T P}
$$

Total Nitrogen (TN):

$$
\frac{\partial C_{T N}}{\partial t}=-V \frac{\partial C_{T N}}{\partial x}+\frac{1}{A_{x}} \frac{\partial}{\partial x}\left(A_{x} D_{x} \frac{\partial C_{T N}}{\partial x}\right)+\frac{q_{L i n}}{A_{x}}\left(C_{T N}^{L}-C_{T N}\right)+\frac{q_{g w d}}{A_{x}}\left(C_{T N}^{g w}-C_{T N}\right)-K_{T N} C_{T N}
$$


Organic Nitrogen $(\mathrm{ON})$ :

$$
\begin{gathered}
\frac{\partial C_{O N}}{\partial t}=-V \frac{\partial C_{O N}}{\partial x}+\frac{1}{A_{x}} \frac{\partial}{\partial x}\left(A_{x} D_{x} \frac{\partial C_{O N}}{\partial x}\right)+\frac{q_{L i n}}{A_{x}}\left(C_{O N}^{L}-C_{O N}\right) \\
+\frac{q_{g w d}}{A_{x}}\left(C_{O N}^{g w}-C_{O N}\right)-K_{O N} C_{O N}+J_{R O N}
\end{gathered}
$$

Ammonium Nitrogen (AN):

$$
\begin{aligned}
& \frac{\partial C_{A N}}{\partial t}=-V \frac{\partial C_{A N}}{\partial x}+\frac{1}{A_{x}} \frac{\partial}{\partial x}\left(A_{x} D_{x} \frac{\partial C_{A N}}{\partial x}\right)+\frac{q_{L i n}}{A_{x}}\left(C_{A N}^{L}-C_{A N}\right) \\
& +\frac{q_{g w d}}{A_{x}}\left(C_{A N}^{g w}-C_{A N}\right)+K_{O N} C_{O N}-K_{A N} C_{A N}-J_{U A N}
\end{aligned}
$$

Nitrate Nitrogen $(\mathrm{NN})$ :

$$
\begin{aligned}
& \frac{\partial C_{N N}}{\partial t}=-V \frac{\partial C_{N N}}{\partial x}+\frac{1}{A_{x}} \frac{\partial}{\partial x}\left(A_{x} D_{x} \frac{\partial C_{N N}}{\partial x}\right)+\frac{q_{L i n}}{A_{x}}\left(C_{N N}^{L}-C_{N N}\right) \\
& +\frac{q_{g w d}}{A_{x}}\left(C_{N N}^{g w}-C_{N N}\right)+\psi K_{A N} C_{A N}-K_{N N} C_{N N}-J_{U N N}
\end{aligned}
$$

where $C$ is the concentration $\left(M / L^{3}\right), C^{L}$ is the lateral concentration $\left(M / L^{3}\right), C g w$ is the concentration in groundwater $\left(M / L^{3}\right), K$ is the first order loss rate constant $(1 / T), A_{x}$ is the cross-sectional area in $x$-direction $\left(L^{2}\right), D_{x}$ is the dispersion coefficient $\left(L^{2} / T\right), q_{L i n}$ is the lateral inflow $\left(L^{2} / T\right), q_{g} w d$ is the groundwater discharge $\left(L^{2} / T\right), J_{R O N}$ is the release flux of organic nitrogen from biomass $(M / T)$, JUAN is the uptake flux of ammonium nitrogen absorbed by biomass $(M / T), J_{U N N}$ is the uptake flux of nitrate nitrogen absorbed by biomass $(M / T), \psi$ is the fraction of ammonium that is nitrified, and TP,TN, ON, AN, NN are the subscripts denoting total phosphorus, total nitrogen, organic nitrogen, ammonium nitrogen, and nitrate nitrogen, respectively.

\subsection{Visual MODular Finite-Difference FLOW model (MODFLOW)}

Visual MODFLOW is a three-dimensional groundwater flow and contaminant transport model that integrates several packages such as MODFLOW-2000, SEAWAT, MODPATH, MT3DMS, MT3D99, RT3D, VMOD 3D-Explorer, WinPEST, Stream Routing, Zone Budget, MGO, SAMG, and PHT3D.

MODFLOW (Modular Three-Dimensional Finite-Difference Ground-Water Flow Model) package solves the three-dimensional ground-water flow equation for a porous medium by using a finite-difference method. MODFLOW is first developed by United States Geological Survey (USGS) (McDonald \& Harbaugh, 1988), then continuously improved and enhanced (Harbaugh \& McDonald, 1996a; Harbaugh \& McDonald, 1996b; Harbaugh et al., 2000; Harbaugh, 2005) and finally integrated into Visual MODFLOW. The three-dimensional movement of groundwater of constant density through porous earth material may be described by the following partial-differential equation (McDonald \& Harbaugh, 1988):

$$
\frac{\partial}{\partial x}\left\{K_{x x} \frac{\partial h}{\partial x}\right\}+\frac{\partial}{\partial y}\left\{K_{y y} \frac{\partial h}{\partial y}\right\}+\frac{\partial}{\partial z}\left\{K_{z z} \frac{\partial h}{\partial z}\right\}+W=S_{s} \frac{\partial h}{\partial t}
$$


where $K_{x x}, K_{y y}$, and $K_{z z}$ are the hydraulic conductivities along the $x, y$, and $z$ coordinate axes, respectively and are assumed to be parallel to the major axes of hydraulic conductivity $(L / T), h$ is the potentiometric head $(L), W$ is a volumetric flux per unit volume and represents sources and/or sinks of water (1/T), $S_{s}$ is the specific storage of the porous material $(1 / L)$, and $t$ is time $(T)$. MODFLOW takes into account the surface and groundwater interactions in wetlands through the RIVER (RIV) boundary condition via a seepage layer separating the surface water body from the groundwater system as shown in Figure 3. River boundary condition simulates the influence of a surface water body such as rivers, streams, lakes, and wetlands on the groundwater flow. The term, which represents the seepage to or from the surface, is added to the groundwater flow equation in this boundary condition. The flow between the surface water and the groundwater system is given by the following equation:

$$
Q_{\text {riv }}=\frac{K L W}{M\left(H_{\text {riv }}-h\right)}
$$

where $Q_{\text {riv }}$ is the flow between the surface water and the aquifer, taken as positive if it is directed into the aquifer, Hriv is the head in the surface water, $L$ and $W$ are the $X-Y$ dimensions of the River boundary grid cells, $M$ is the thickness of the bed of the surface water body, $K$ is the vertical hydraulic conductivity of the bed material of the surface water body, and $h$ is the groundwater head in the cell underlying the River boundary. The term $C_{\text {riv }}=K L W / M$ may be defined as the hydraulic conductance of the surface water-aquifer interconnection which represents the resistance to flow between the surface water body and the groundwater caused by the seepage layer.

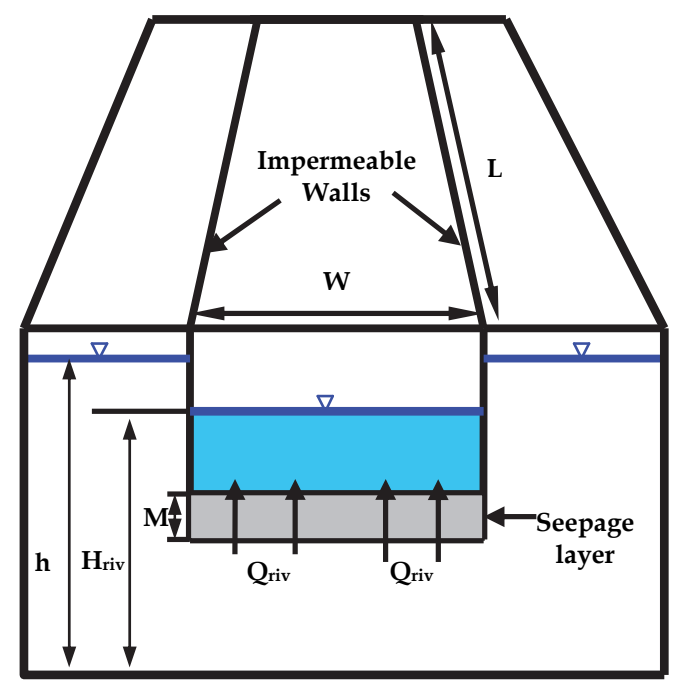

Fig. 3. Schematic of River boundary in MODFLOW (modified after Visual MODFLOW, 2009)

MT3DMS (Modular 3-Dimensional Transport Model, Multi-Species) package solves the three-dimensional contaminant transport in groundwater. MT3D is first developed by Zheng (1990) at S. S. Papadopulos \& Associates, Inc.; subsequently documented for the Robert S. Kerr Environmental Research Laboratory of the U.S. EPA, then continuously 
expanded and finally integrated into Visual MODFLOW as a package. MT3DMS employs three different numerical solution techniques, which are the standard finite-difference method, the particle-tracking-based Eulerian-Lagrangian methods, and the higher-order finite-volume TVD method. It has the capability of simulating advection, dispersion/diffusion, and chemical reactions of contaminants in groundwater flow systems under general hydrogeologic conditions. MT3DMS solves the following partial differential equation which describes the fate and transport of contaminants of species $k$ in 3-D:

$$
\frac{\partial\left(\theta C_{k}\right)}{\partial t}=\frac{\partial}{\partial x_{i}}\left(\theta D_{i j} \frac{\partial C_{k}}{\partial x_{j}}\right)-\frac{\partial}{\partial x_{i}}\left(\theta v_{i} C^{k}\right)+q_{s} C_{k}^{s}+\sum R_{n}
$$

where $\theta$ is the porosity of the subsurface medium (dimensionless), $C_{k}$ is the dissolved concentration of species $k\left(M L^{-3}\right), t$ is time $(T), x_{i, j}$ is the distance along the respective Cartesian coordinate axis $(L), D_{i j}$ is the hydrodynamic dispersion coefficient tensor $\left(L^{2} T^{-1}\right), v_{i}$ is the seepage or linear pore water velocity $\left(L T^{-1}\right), q_{s}$ is the volumetric flow rate per unit volume of aquifer representing fluid sources (positive) and sinks (negative) ( $\left.\mathrm{T}^{-1}\right), C_{k}^{s}$ is the concentration of the source or sink flux for species $k\left(M L^{-3}\right)$, and $\sum R_{n}$ is the chemical reaction term $\left(M L^{-3} T^{-1}\right)$. The transport equation is related to the flow equation through the Darcy's Law:

$$
v_{i}=\frac{q_{i}}{\theta}=-\frac{K_{i}}{\theta} \frac{\partial h}{\partial x_{i}}
$$

where $K_{i}$ is the principal component of the hydraulic conductivity tensor $\left(L T^{-1}\right)$ and $h$ is the hydraulic head $(L)$. The hydraulic head is obtained from the solution of the threedimensional groundwater flow equation (Eqn. 11), which is solved by MODFLOW package.

\subsection{Environmental Protection Agency Storm Water Management Model (EPA SWMM)}

Environmental Protection Agency Storm Water Management Model (EPA SWMM) is a dynamic rainfall-runoff simulation model of a watershed for a single storm event or for continuous simulation of multiple storms. EPA SWMM also models groundwater flow within the aquifer underlying each subcatchment of the watershed and the interflow between groundwater and the drainage system. The model is extensively used to plan, analyze, and control storm water runoff; to design drainage system components; and to evaluate watershed management of both urban and non-urban areas (Huber and Dickinson, 1988; Rossman, 2010). With the analyses of EPA SWMM, the quantity and quality of surface runoff on each subcatchment; the flow rate, depth, and concentration in each conduit; and groundwater flow and groundwater elevation in each aquifer are obtained. Among the EPA SWMM inputs are precipitation data, subcatchment delineation, pipe system characteristics, and aquifer and soil properties. Change of flow rate (hydrograph), change of groundwater depth, and change of concentration (pollutograph) through time and total simulation summaries are obtained at the end of the analysis.

In EPA SWMM, while precipitation and flow from upstream subcatchments are considered as inflow, infiltration and evaporation are considered as outflow in surface runoff calculation. Flow rate in each conduit is calculated by using the continuity and momentum equations for flood routing. The most general form of flood routing equations is the dynamic wave 
equations or also known as St. Venant equations which describe unsteady and gradually varied flow. By neglecting the inertial terms in the momentum equation, diffusion wave equations are obtained and by neglecting both inertial and pressure terms, kinematic wave equations are obtained. One can select anyone of these equations as the flood routing option in EPA SWMM according to the characteristics of the modeled watershed. The dynamic wave equations for flow routing in conduits are given as follows (Eagleson, 1970):

$$
\begin{gathered}
\frac{\partial Q}{\partial x}+\frac{\partial A}{\partial t}=0 \\
\frac{1}{A} \frac{\partial Q}{\partial t}+\frac{1}{A} \frac{\partial Q}{\partial x}\left(\frac{Q^{2}}{A}\right)+g \frac{\partial y}{\partial x}-g\left(S_{0}-S_{f}\right)=0
\end{gathered}
$$

where $Q$ is flow rate $\left(L^{3} / T\right), A$ is cross-sectional area $\left(L^{2}\right), y$ is water depth $(L), S_{f}$ is friction slope $(L / L), S_{0}$ is bed slope $(L / L), g$ is gravitational acceleration $\left(L / T^{2}\right), t$ is time $(T)$, and $x$ is distance $(L)$. The kinematic wave equation from dynamic wave equations follows (Lighthill and Whitham, 1955):

$$
\left.\begin{array}{l}
\frac{\partial A}{\partial t}+\frac{\partial Q}{\partial x}=0 \\
Q=\alpha A^{m}
\end{array}\right\} \Rightarrow \frac{\partial A}{\partial t}+\alpha \frac{\partial\left(A^{m}\right)}{\partial x}=0
$$

where $a$ and $m$ are given according to the flow rate-friction slope relationship. The diffusion wave equation from dynamic wave equations follows (Ponce, 1989):

$$
\left.\begin{array}{l}
\frac{\partial A}{\partial t}+\frac{\partial Q}{\partial x}=0 \\
S_{f}=S_{0}-\frac{\partial y}{\partial x}
\end{array}\right\} \Rightarrow \frac{\partial Q}{\partial t}+c \frac{\partial Q}{\partial x}=K \frac{\partial^{2} Q}{\partial x^{2}} \quad c=\frac{\partial Q}{\partial A} \quad K=\frac{Q}{2 B S_{0}}
$$

where $c$ is the diffusion wave celerity $(L / T), K$ is the hydraulic diffusivity $\left(L^{2} / T\right)$, and $B$ is the width $(L)$. EPA SWMM has three options for infiltration calculation which are the GreenAmpt Method, the Integrated Horton Method and the SCS Curve Number Method. The equations for each method are given as follows:

Green-Ampt Method (Huber and Dickinson, 1988):

$$
\begin{aligned}
& \text { for } F<F_{s}: f=i \\
& \text { if } i>K_{s} \Rightarrow \mathrm{F}_{\mathrm{s}}=\frac{S_{u} M}{i / K_{s}-1} \\
& \text { if } i<K_{s} \Rightarrow F_{s} \text { is not calculated. } \\
& \text { for } \underline{F \geq F_{s}}: f=f_{p} \text { and } f_{p}=K_{s}\left(1+\frac{S_{u} M}{F}\right)
\end{aligned}
$$

where $F$ is the cumulative infiltration $(L), F_{S}$ is the cumulative infiltration of saturated soil $(L), i$ is the rainfall intensity $(L / T), K_{s}$ is the hydraulic conductivity for saturated soil $(L / T), S_{u}$ 
is the suction head $(L), M$ is the initial moisture deficit $(L / L), f$ is the infiltration rate $(L / T)$, and $f_{p}$ is the infiltration capacity $(L / T)$.

Integrated Horton Method (Huber and Dickinson, 1988):

$$
f_{p}=f_{\infty} t+\left(f_{0}-f_{\infty}\right) e^{-\alpha t} \quad f(t)=\min \left[f_{p}(t), i(t)\right] \quad F(t)=\int_{0}^{t} f(\tau) d \tau
$$

where $f_{\infty}$ is minimum infiltration capacity $(L / T), f_{0}$ is infiltration capacity for dry soil $(L / T)$, and $a$ is a constant $(1 / T)$.

SCS Curve Number Method (Ponce and Hawkins, 1996):

$$
\begin{gathered}
\frac{F}{S}=\frac{Q}{P-I_{a}} \\
P=Q+I_{a}+F
\end{gathered}
$$

where $F$ is actual retention $(L), S$ is potential retention $(L), Q$ is actual runoff $(L), P$ is potential runoff $(L)$, and $I_{a}$ is initial abstraction $(L)$.

The rate of groundwater flow as shown in Figure 4 is calculated as a function of groundwater and surface water levels with the following general equation (Rossman, 2010):

$$
Q_{g w}=A_{1}\left(H_{g w}-H^{*}\right)^{B_{1}}-A_{2}\left(H_{s w}-H^{*}\right)^{B_{2}}+A_{3}\left(H_{g w} H_{s w}\right)
$$

where $Q_{g w}$ is the groundwater flow rate per unit area $\left(L^{3} T^{-1} / L^{2}\right), H_{g w}$ is the height of saturated zone above bottom of aquifer $(L), H_{s w}$ is the height of surface water at receiving node above aquifer bottom $(L), H^{*}$ is the threshold groundwater height $(L), A_{1}$ is the groundwater flow coefficient, $B_{1}$ is the groundwater flow exponent, $A_{2}$ is the surface water flow coefficient, $B_{2}$ is the surface water flow exponent, and $A_{3}$ is the surface and groundwater interaction coefficient. If groundwater flow rate per unit area is calculated by using the Darcy's Law, Equation (24) becomes:

$$
Q_{g w}=k \frac{\left(H_{g w}-H_{s w}\right)}{L_{a}}
$$

where $A_{1}=A_{2}=k / L_{a}, k$ is the hydraulic conductivity $(L / T)$ and $L_{a}$ is the length of the aquifer, $B_{1}=B_{2}=1$, and $H^{*}=A_{3}=0$. Dupuit-Forcheimer leakage equation is used in groundwater flow calculation, in order to take into account surface and groundwater interactions in watershed modeling:

$$
q_{\text {dupuit }}=\frac{k}{2 L_{a}}\left(h_{1}^{2}-h_{2}^{2}\right)
$$

where $h_{1}$ is the elevation of the highest point of the water table $(L), h_{2}$ is the elevation of the water surface in the channel $(L)$ and $q_{\text {dupuit }}$ is the flow rate per unit length $\left(L^{2} / T\right)$. If we substitute for $h_{1}=2 H_{g w}-h_{2}$ by assuming that $H_{g w}$ is an average value over the entire horizontal extent of the saturated zone of the aquifer and therefore $H_{g w}=\left(h_{1}+h_{2}\right) / 2 ; H_{s w}=h_{2} ;$ and $Q_{g w}=q_{\text {dupuit }} / B, B$ being the aquifer thickness $(L)$ in Dupuit-Forcheimer equation, Equation (26) becomes as follows: 


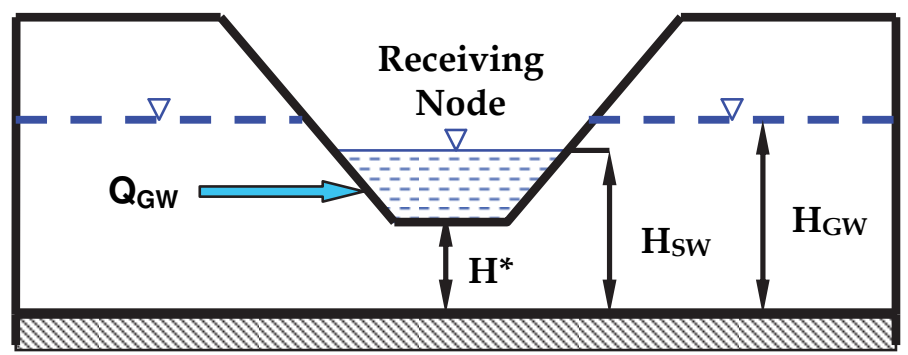

Fig. 4. Schematic of groundwater flow in EPA SWMM (modified after Rossman, 2010)

$$
Q_{g w}=\frac{2 k}{B L_{a}}\left(H_{g w}^{2}-H_{g w} H_{s w}\right)
$$

When Equation (27) is compared with Equation (24), we see that $A_{1}=2 k / B L_{a}, B_{1}=2$, $\mathrm{A}_{2}=B_{2}=H^{*}=0$ and $A_{3}=-2 k / B L_{a}$.

\section{Applications}

Applications of the models discussed in the previous section are presented in this section. Each model is used to simulate a different case study and shows different aspects of surface and groundwater interactions and the impact of hydraulic conductivity for different scenarios. For comparison purposes, the same set of lateral and vertical hydraulic conductivity values are used in each application. The simulations are conducted under four different combinations of the conductivity values: (A) $K_{x}=K_{z}=0.01 \mathrm{~m} / \mathrm{hr}$, (B) $K_{x}=0.01 \mathrm{~m} / \mathrm{hr}$ and $K_{z}=0.001 \mathrm{~m} / \mathrm{hr}$, (C) $K_{x}=0.1 \mathrm{~m} / \mathrm{hr}$ and $K_{z}=0.01 \mathrm{~m} / \mathrm{hr}$, and (D) $K_{x}=K_{z}=0.001 \mathrm{~m} / \mathrm{hr}$.

\subsection{Case study using WETSAND}

An application of WETSAND model is presented for Duke University restored wetland site located in North Carolina, USA. The model is simulated to show the importance of surface and groundwater interactions on surface water and nitrogen concentration in wetland and the role of lateral and vertical hydraulic conductivity on surface and groundwater interactions.

The study site is located in the Sandy Creek watershed, in the southern section of Durham County in North Carolina, United States with an area of 554.41 ha (1,370 acres). Storm water runoff generated over part of the Duke University campus and part of the City of Durham flows into the wetland area; its peak flow decreases and its water quality improves after reaching the wetland site. The stream restoration project within the wetland area is completed by closing part of the original streambed of Sandy Creek and opening a new streambed with more meanders. Over $579 \mathrm{~m}$ (1900 ft) of stream restoration aims enhancing water flow over the floodplain and removal of nutrients and sediments. Figure 5A shows the position of the wetland site, the boundary of Duke University campus and the tributaries of the Sandy Creek within the Duke University campus area. Figure 5B shows the topography of the restored wetland site and restored part of the Sandy Creek, a total of 20 groundwater sampling well locations and the flooded area behind the earthen dam. The earthen dam was completed also as part of the wetland restoration project which allows for altering the water level in the stream and wetlands. 


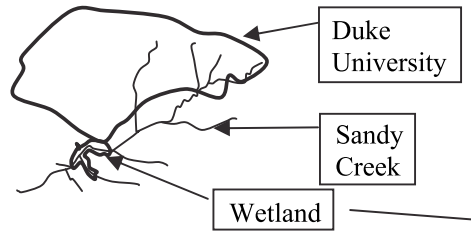

(A)
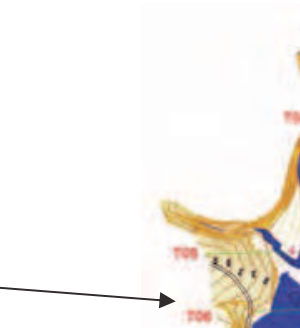

(B)

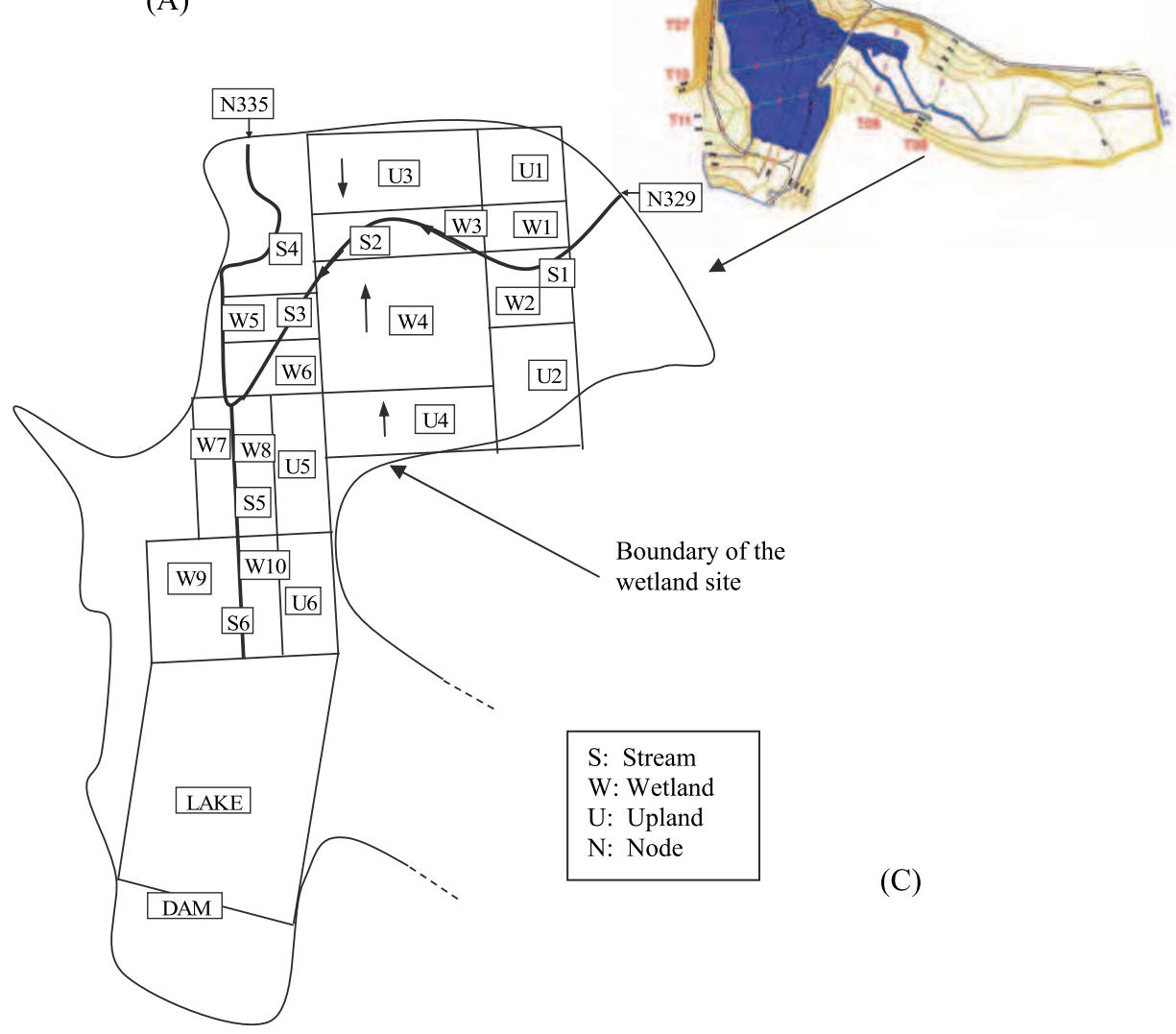

Fig. 5. (A) Boundary of Duke University and wetland site. (B) Restored wetland and stream site at Sandy Creek in Duke Forest (Duke Wetland Center). Contour lines (shown with yellow color) are shown at $30 \mathrm{~cm}$. The stream and lake restoration areas are shown with blue color in the map. Numbers along green lines (T) indicate water well locations. (C) Discretization of the Duke University wetland site (Kazezyllmaz-Alhan et al, 2007). Maps shown are not to scale.

\subsubsection{Results and discussion}

The WETSAND model has been applied to the Duke University restored wetland site to investigate the role of lateral and vertical hydraulic conductivity on surface and 
groundwater interactions in terms of wetland hydrology and wetland water quality. For this purpose, first, the study site is discretized into six upland (U) and ten wetland (W) sections and six stream (S) segments (Figure 5C). Nodes N329 and N335 are the receiving nodes of upstream surface runoff. The simulations are conducted by using the rainfall data collected at the nearby Duke Forest Site and groundwater level data recorded by Duke University Wetland Center investigators during year 2002. The average monthly temperature for Durham, NC is obtained from the NOAA National Climatic Data Center (NCDC). Change of surface water depth and concentration of total nitrogen through time are obtained for the case with interaction effect included and with no interaction effect included on each wetland section. Note that, WETSAND provides us with the opportunity to compare interaction and no interaction cases. Here, the results obtained on wetland section four (W4) is presented where we observe groundwater recharge for the major part of the simulation and groundwater discharge towards the end of the simulation.

Figure 6 shows the change of surface water depth on wetland section W4 for different lateral and vertical hydraulic conductivity values with surface and groundwater interaction and with no surface and groundwater interaction. First, we observe that low vertical hydraulic conductivity value $\left(K_{z}=0.001 \mathrm{~m} / \mathrm{hr}\right)$ in Figures $6 \mathrm{~B}$ and $6 \mathrm{D}$ results in higher water depths on the surface as compared to high vertical conductivity value $\left(K_{z}=0.01 \mathrm{~m} / \mathrm{hr}\right)$ in Figures $6 \mathrm{~A}$ and $6 \mathrm{C}$. Then, when Figures $6 \mathrm{~B}$ and $6 \mathrm{D}$ are compared, we observe that the difference between the surface water depth with interaction effect included and with no interaction effect included is higher in Figure 6B where lateral hydraulic conductivity is $K_{x}=0.01 \mathrm{~m} / \mathrm{hr}$ than in Figure 6D where lateral hydraulic conductivity is $K_{x}=0.001 \mathrm{~m} / \mathrm{hr}$. Thus, we conclude that as lateral hydraulic conductivity increases, the effect of surface and groundwater interaction also increases. Moreover, the surface water depth is lower with the surface and groundwater interaction effect for the most part of the simulation as mostly groundwater recharge is observed throughout the simulation on wetland section W4 (Figure 7). When Figures 6A and 6B are compared, eventhough the lateral hydraulic conductivity values are the same, we observe higher difference between the surface water depth with interaction effect and with no interaction effect in Figure 6B. We link this result to different vertical conductivity values: Since the vertical hydraulic conductivity in Figure 6A is higher than the one in Figure 6B, most of the surface water infiltrates into ground in Figure 6A and therefore for both with interaction and no interaction, surface water depth takes the value of about zero. Thus, the vertical hydraulic conductivity plays an indirect role on surface and groundwater interactions especially for the parts where groundwater recharge is dominant. Finally, when Figures 6A and 6C are compared, in the last portion of Figure 6C, we observe a relatively large difference between the surface water depths with interaction and no interaction and the surface water is higher for the case with interaction this time. The reason is that the groundwater discharge comes to the stage in the last part of the simulation (Figure 7) and high lateral hydraulic conductivity $\left(K_{x}=0.1 \mathrm{~m} / \mathrm{hr}\right)$ in Figure $6 \mathrm{C}$ results in an increase in difference of surface water for interaction and no interaction.

Figure 8 shows the change of total Nitrogen concentration on wetland section W4 again for the same set of lateral and vertical hydraulic conductivity values with surface and groundwater interaction and with no surface and groundwater interaction. When Figure 8B and $8 \mathrm{D}$ are compared, we observe that high lateral hydraulic conductivity value in Figure $8 \mathrm{~B}\left(K_{x}=0.01 \mathrm{~m} / \mathrm{hr}\right)$ results in higher difference between the concentration with interaction and with no interaction. Further, we observe that the concentration for the case with interaction is in general lower than the one with no interaction except for the last part where 
groundwater discharges in this portion. In the last part, the concentration value reaches about $1.5 \mathrm{mg} / 1$ in all figures (Figures 8A-8D), because the total nitrogen concentration in groundwater is defined as $1.5 \mathrm{mg} / \mathrm{l}$. In other words, for the time periods where there is a groundwater discharge, the concentration on the wetland takes the value of groundwater concentration if the surface and groundwater interaction is incorporated into the simulation. For the case with no interaction, the concentration at wetland site reaches a value of only about $0.5 \mathrm{mg} / 1$. Thus, we conclude that it is extremely important to incorporate surface and groundwater interactions into the simulation models as neglecting this physical situation may cause a huge difference in the analysis for certain cases. Moreover, the role of lateral hydraulic conductivity on surface and groundwater interaction is important also in terms of concentration and as lateral hydraulic conductivity increases, the effect of surface and groundwater interaction on concentration also increases. When Figures $8 \mathrm{~A}$ and $8 \mathrm{~B}$ are compared, we observe that high vertical hydraulic conductivity $\left(K_{z}=0.01 \mathrm{~m} / \mathrm{hr}\right)$ results in less oscillation in concentration values and concentration in general reaches a steady state
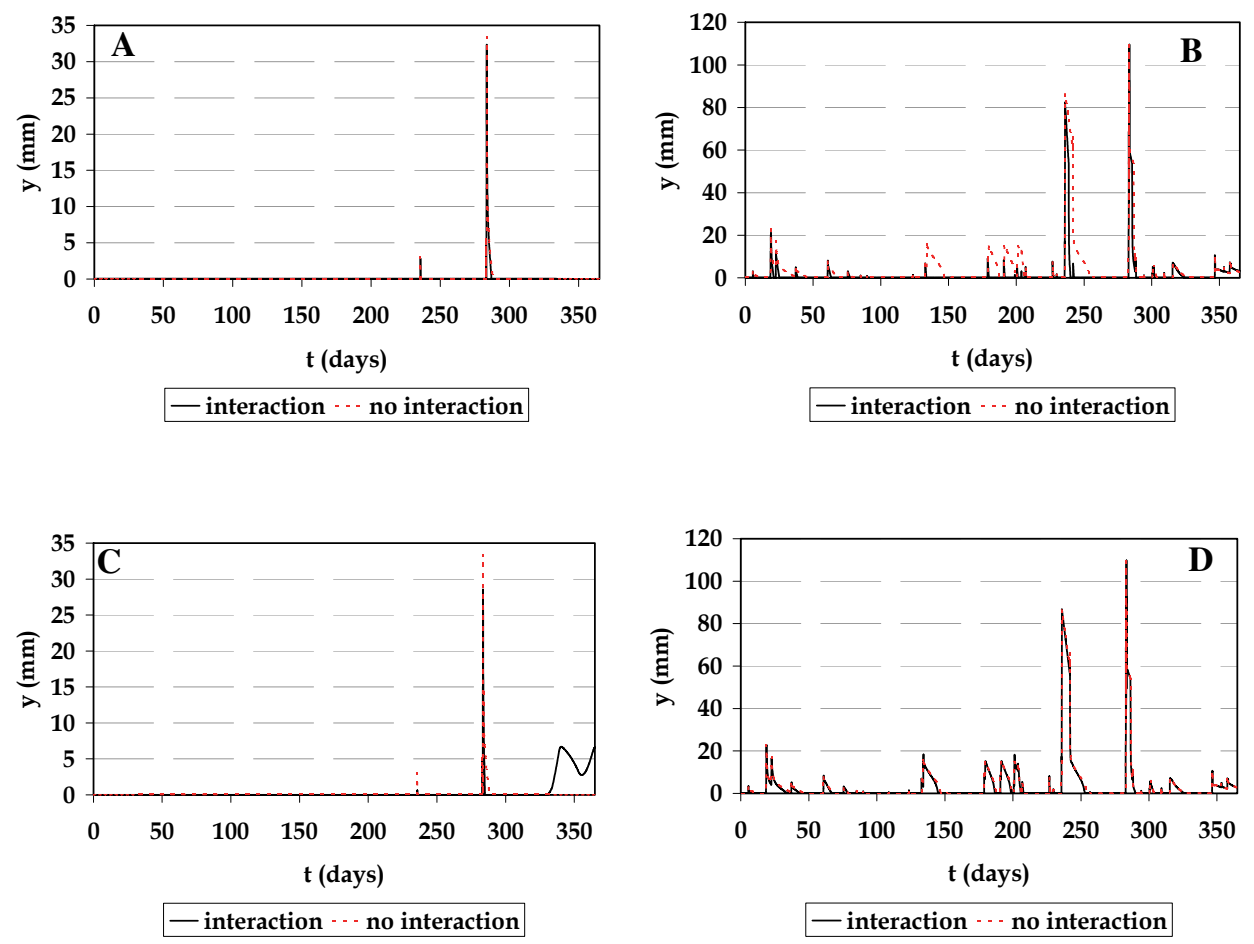

Fig. 6. Comparison of surface water depth on wetland section W4 with surface and groundwater interaction and with no surface and groundwater interaction (A) $K_{x}=K_{z}=0.01$ $\mathrm{m} / \mathrm{hr},(\mathrm{B}) K_{x}=0.01 \mathrm{~m} / \mathrm{hr}$ and $K_{z}=0.001 \mathrm{~m} / \mathrm{hr},(\mathrm{C}) K_{x}=0.1 \mathrm{~m} / \mathrm{hr}$ and $K_{z}=0.01 \mathrm{~m} / \mathrm{hr},(\mathrm{D})$ $K_{x}=K_{z}=0.001 \mathrm{~m} / \mathrm{hr}$. 


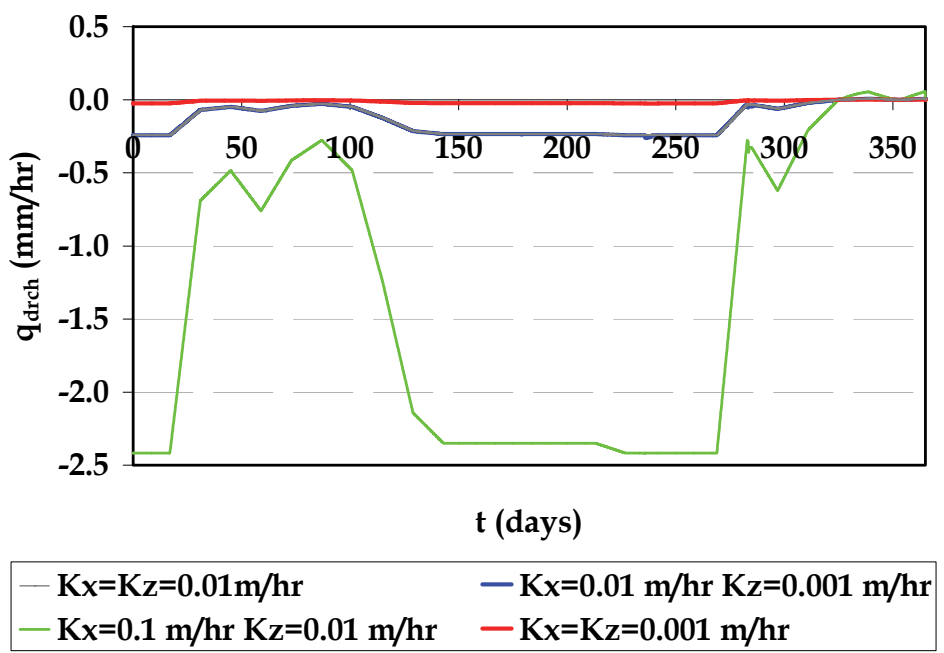

Fig. 7. Water flux between surface and ground on wetland section W4.
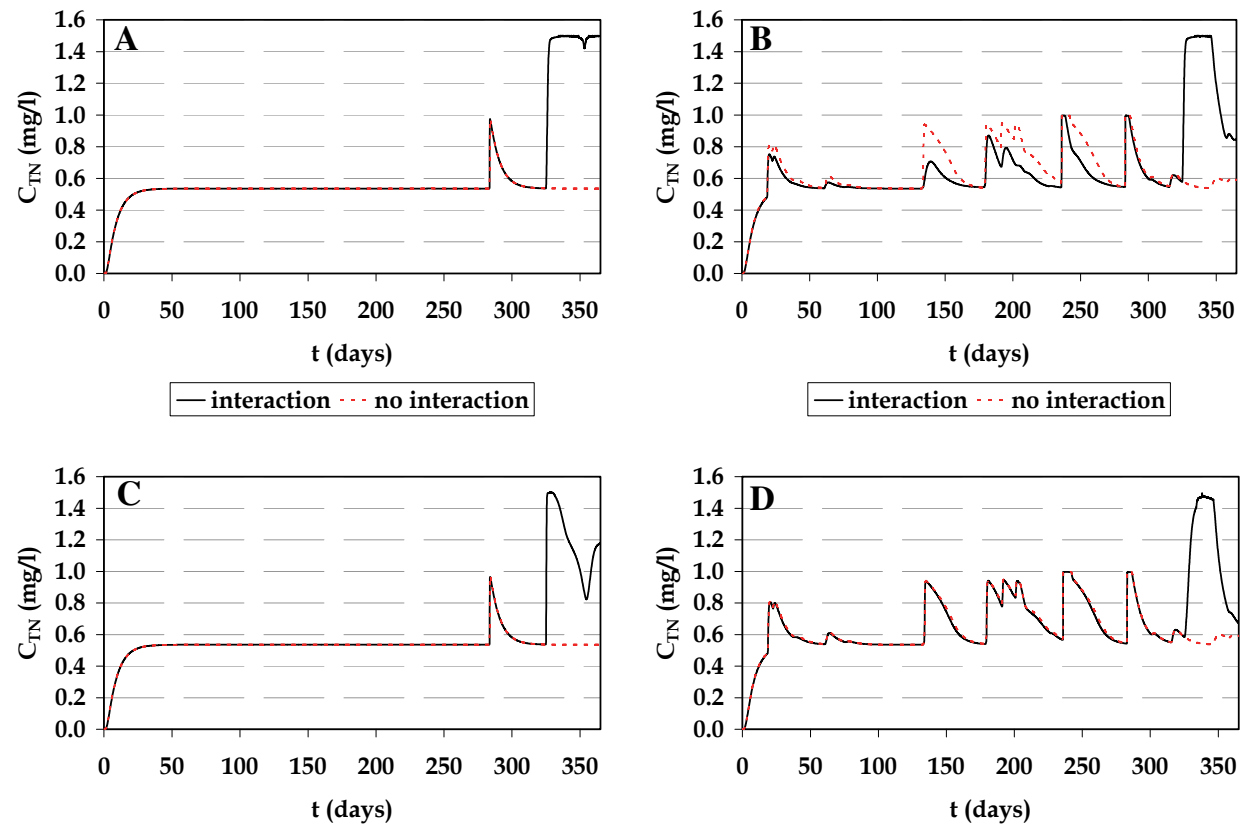

-interaction $\cdots$ no interaction

-interaction -.. no interaction

Fig. 8. Comparison of total nitrogen concentration in surface water on wetland section W4 with surface and groundwater interaction and with no surface and groundwater interaction (A) $K_{x}=K_{z}=0.01 \mathrm{~m} / \mathrm{hr}$, (B) $K_{x}=0.01 \mathrm{~m} / \mathrm{hr}$ and $K_{z}=0.001 \mathrm{~m} / \mathrm{hr},(\mathrm{C}) K_{x}=0.1 \mathrm{~m} / \mathrm{hr}$ and $K_{z}=0.01$ $\mathrm{m} / \mathrm{hr},(\mathrm{D}) K_{x}=K_{z}=0.001 \mathrm{~m} / \mathrm{hr}$. 
value of about $0.5 \mathrm{mg} / 1$ for both with interaction and no interaction. Thus, the vertical hydraulic conductivity plays an indirect role on surface and groundwater interactions especially for the parts where groundwater recharge is dominant. As the vertical hydraulic conductivity increases, the effect of surface and groundwater interaction on concentration decreases.

\subsection{Case study using MODFLOW}

An application of Visual MODFLOW is presented by using a wetland-aquifer conceptual model. The model is simulated to show different fluxes between wetland surface water and groundwater for different hydraulic conductivities and their effects on concentration distribution in groundwater.

\subsubsection{Conceptual model}

A model domain of $2000 \mathrm{~m} \times 2000 \mathrm{~m}$ with $20 \times 20$ cells is selected. The aquifer has one layer with a thickness of $10 \mathrm{~m}$; the porosity and the specific storage are selected as $\theta=0.5$ and $S_{s}=10^{-5} \mathrm{~m}^{-1}$, respectively. A wetland site of $300 \mathrm{~m} \times 1300 \mathrm{~m}$ is defined within the model domain. The surface water depth at the wetland site is selected as $1 \mathrm{~m}$ and $10 \mathrm{mg} / \mathrm{l}$ of contaminant is assigned to the wetland site for a duration of $100,000 \mathrm{sec}$ (Figure 9).

\subsubsection{Results and discussion}

The influence of hydraulic conductivity on surface and groundwater interactions in groundwater flow and groundwater contaminant transport modeling is simulated with different conductivity values at a wetland site. Figure 10 shows the water flux between surface water and groundwater along the wetland. Positive values stand for groundwater recharge and negative values stand for groundwater discharge. As it can be seen from the figure, as the lateral hydraulic conductivity increases, the flow between surface water and groundwater also increases in both directions. On the other hand, we don't observe a significant difference between the cases where $K_{x}=K_{z}=0.01 \mathrm{~m} / \mathrm{hr}$ and $K_{\mathrm{x}}=0.01 \mathrm{~m} / \mathrm{hr}$, $\mathrm{K}_{\mathrm{z}}=0.001 \mathrm{~m} / \mathrm{hr}$. Thus, vertical hydraulic conductivity does not play a significant role on surface and groundwater interactions when Visual MODFLOW results are considered.

Figure 11 shows the concentration distribution in groundwater due to the contaminant defined in surface water at the wetland site for the four set of lateral and vertical hydraulic conductivities. As it can be seen from the figure, for the cases where vertical hydraulic conductivity is $K_{z}=0.01 \mathrm{~m} / \mathrm{hr}$ (Figure 11A) and $K_{z}=0.001 \mathrm{~m} / \mathrm{hr}$ (Figure 11B), the concentration distribution in groundwater differs slightly and reaches the value of $1 \times 10^{-5}$ $\mathrm{mg} / \mathrm{l}$ towards the mid-portion of the wetland site. When Figures $11 \mathrm{~A}$ and $11 \mathrm{C}$ are compared, where the lateral hydraulic conductivity is $K_{x}=0.01 \mathrm{~m} / \mathrm{hr}$ and $K_{x}=0.1 \mathrm{~m} / \mathrm{hr}$, respectively, we see a significant difference in concentration distributions. For the case of $K_{x}=0.1 \mathrm{~m} / \mathrm{hr}$, the concentration reaches a value of $5 \times 10^{-4} \mathrm{mg} / \mathrm{l}$. Thus, when the lateral hydraulic conductivity increases, the mass flux and therefore the concentration in groundwater also increases. When Figure 11D is considered, we observe a small fraction of pollutant passed to the groundwater.

We observe that the concentration distribution is observed only in the upper portion of the wetland site where groundwater recharges (see Figure 10). On the other hand, we don't see any contaminant in groundwater in the lower portion of the wetland site where groundwater discharges. Since Visual MODFLOW simulates contaminant transport in 
groundwater, the results show only pollutants in groundwater due to the mass flux from surface water to groundwater. If contaminant transport in surface water could be simulated, we would expect to see a decrease in surface water concentration in the lower portion of the wetland due to the mass flux of pure water from ground to surface.

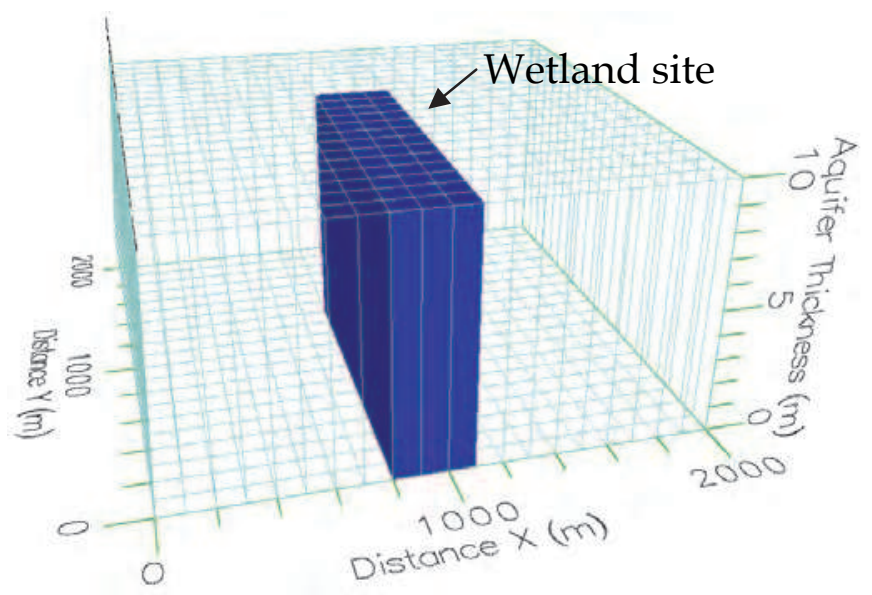

Fig. 9. Schematic of the conceptual wetland-aquifer system.

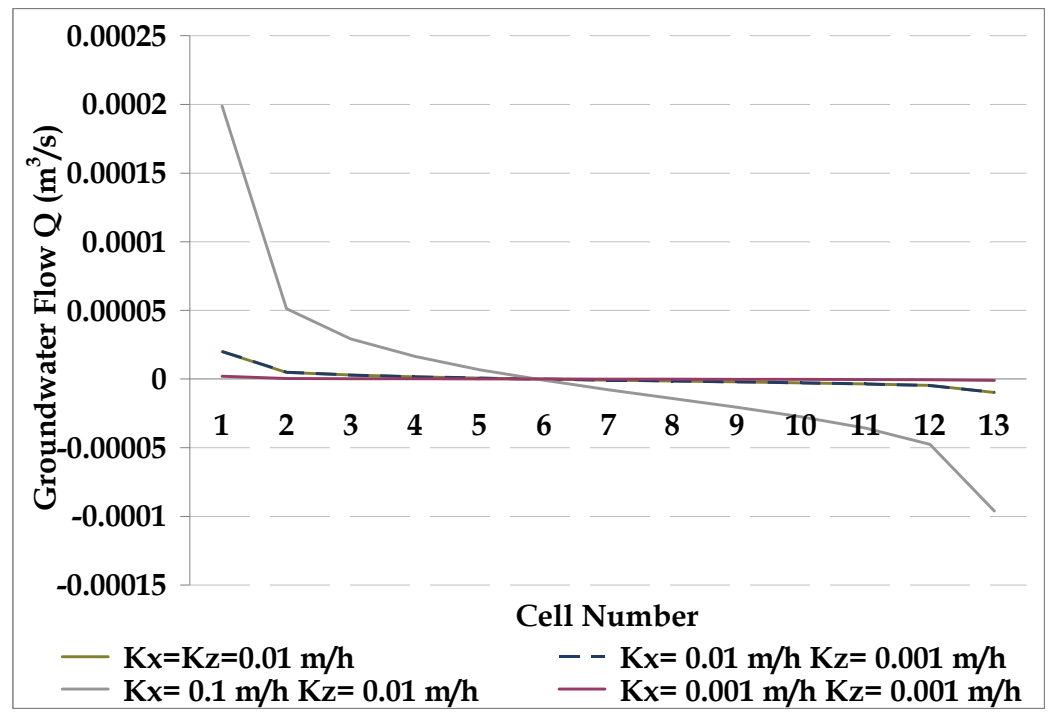

Fig. 10. Water flux between surface and ground on wetland-aquifer system.

\subsection{Case study using EPA SWMM}

An application of EPA SWMM is presented for Büyükçekmece wetland site located in Istanbul, Turkey. The model is simulated to show the influence of surface and groundwater 
interactions on groundwater depth and flow and surface runoff concentration and the role of lateral and vertical hydraulic conductivities on surface and groundwater interactions.

Büyükçekmece wetland site is located at downstream point of Büyükçekmece Lake in Büyükçekmece Watershed, Istanbul and is one of the most important wetlands of Turkey. Büyükçekmece Watershed has a drainage area of $622 \mathrm{~km}^{2}$ and supplies a major part of Istanbul's drinking water. A lagoon connects Büyükçekmece Lake with the Marmara Sea. In order to protect the environmental habitat of the lake, a dam was constructed at lakelagoon-sea interface. About 18 streams gather flow generated over the catchment which are connected to 3 rivers and the rivers flow through the wetland site and reaches the lake. There exist three types of aquifers under Büyükçekmece Watershed: local spaced and cracked Kirklareli limestone, local cracked metamorphic units classified as Istıranca group, and local granular aquifer specified as Pınarhisar formation (Birpınar et al, 2006). The boundaries of Büyükçekmece Watershed and Büyükçekmece wetland site are shown in Figure 12.

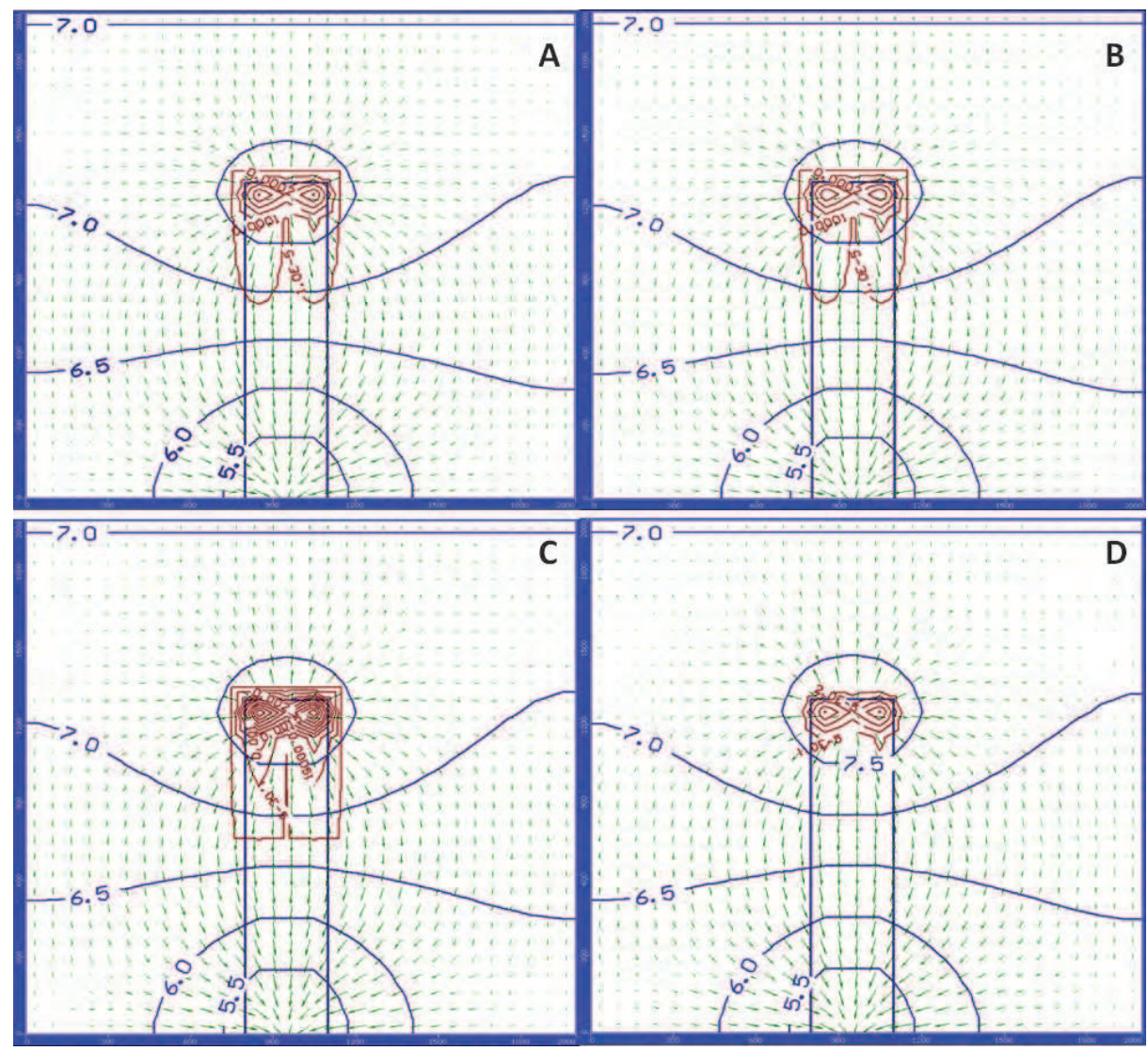

Fig. 11. Concentration distribution (shown with red color in $\mathrm{mg} / \mathrm{l}$ ) in groundwater (A) $K_{x}=K_{z}=0.01 \mathrm{~m} / \mathrm{hr}$, (B) $K_{x}=0.01 \mathrm{~m} / \mathrm{hr}$ and $K_{z}=0.001 \mathrm{~m} / \mathrm{hr}$, (C) $K_{x}=0.1 \mathrm{~m} / \mathrm{hr}$ and $K_{z}=0.01 \mathrm{~m} / \mathrm{hr}$, (D) $K_{x}=K_{z}=0.001 \mathrm{~m} / \mathrm{hr}$. 


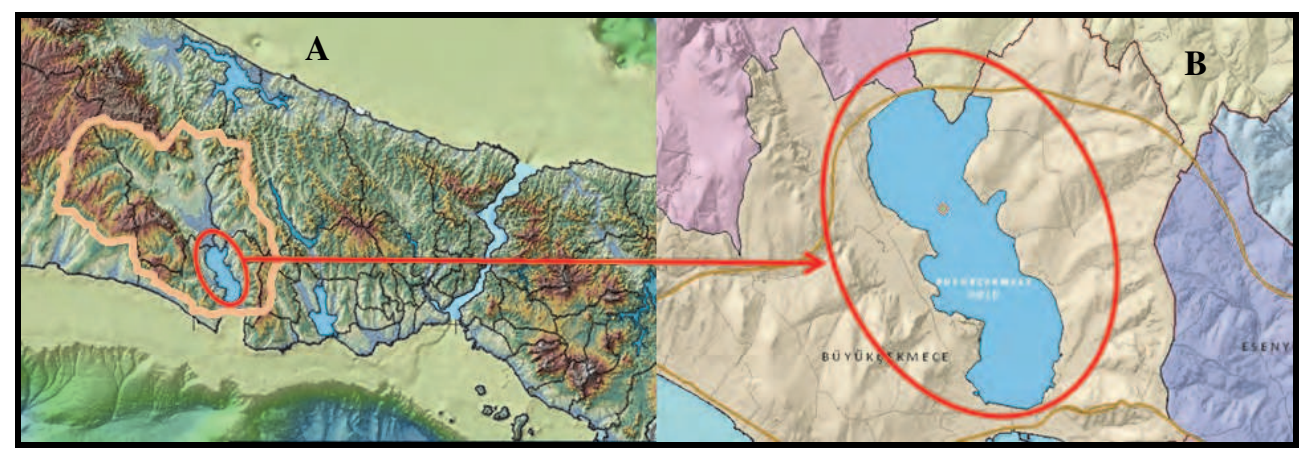

Fig. 12. Büyükçekmece watershed (A) and Büyükçekmece wetland site around Büyükçekmece Lake (B) (Google Earth).

\subsubsection{Results and discussion}

EPA SWMM has been applied to Büyükçekmece wetland site in order to observe surface and groundwater interactions in groundwater. For this purpose, first a hydrological model for the site is developed by means of discretizing the region into subcatchments and describing the channels and junctions. Slope, area, and width are input data for each subcatchment; length, cross sectional area, and roughness are input data for each conduit; invert elevation, maximum depth, and inflow are input data for each junction. A total number of 167 subcatchments, 118 conduits, and 157 junctions are defined for the site. In addition, a rain gauge is defined in the model in order to introduce the rainfall data in terms of intensity, volume, or cumulative precipitation.

For groundwater flow and groundwater depth simulation, an aquifer is defined under each subcatchment by porosity, wilting point, field capacity, hydraulic conductivity, conductivity slope, and tension slope. In addition, infiltration is calculated with the Green-Ampt option of EPA SWMM and suction head, hydraulic conductivity, and initial soil moisture deficit are defined as Green-Ampt parameters for each subcatchment. The groundwater flow is simulated according to both Dupuit-Forcheimer leakage equation (Eqn. 27) and Darcy's Law (Eqn. 25) in order to see the difference between the cases with surface and groundwater interaction effect included and not included. Figure 13 shows the hydrological model of Büyükçekmece wetland site. Here, the blue lines represent the subcatchment borders and the red lines represent the conduits, namely open channels.

Figure 14 shows the change of groundwater depth through time on wetland section $44 \mathrm{~s}$ for the cases with interaction effect and with no interaction effect by using the four set of lateral and vertical hydraulic conductivities. As it can be seen from this figure, groundwater depth is affected from both lateral and vertical hydraulic conductivities. For the case with no interaction, the maximum steady state with a value of $3.98 \mathrm{~m}$ has been reached with $K_{x}=K_{z}=0.01 \mathrm{~m} / \mathrm{hr}$ and the minimum steady state with a value of $3.91 \mathrm{~m}$ has been reached with $K_{x}=0.01 \mathrm{~m} / \mathrm{hr}, K_{z}=0.001 \mathrm{~m} / \mathrm{hr}$. The aquifer type with the highest conductivity values, i.e., $K_{x}=0.1 \mathrm{~m} / \mathrm{hr}$ and $K_{z}=0.01 \mathrm{~m} / \mathrm{hr}$ reaches the steady state earliest, whereas the aquifer type with the lowest conductivity values, i.e., $K_{x}=K_{z}=0.001 \mathrm{~m} / \mathrm{hr}$ reaches the steady state latest. We observe a clear difference between the cases with interaction effect included and with no interaction effect included for each combination of lateral and vertical hydraulic 
conductivity value. This difference is greater in the rising part with the lowest conductivity values $K_{x}=K_{z}=0.001 \mathrm{~m} / \mathrm{hr}$ and in the descending part with the highest conductivity values $K_{x}=0.1 \mathrm{~m} / \mathrm{hr}$ and $K_{z}=0.01 \mathrm{~m} / \mathrm{hr}$. Thus, we conclude that both lateral and vertical hydraulic conductivity have a significant impact on surface and groundwater interactions.

Figure 15A shows the groundwater flow through time for the cases with interaction effect and with no interaction effect for the four set of lateral and vertical hydraulic conductivities. As it can be seen from this figure, we observe the largest difference between interaction effect included and not included with the highest conductivity values $K_{x}=0.1 \mathrm{~m} / \mathrm{hr}$ and $K_{z}=0.01 \mathrm{~m} / \mathrm{hr}$. Although it is minor, there is a difference for other combinations of conductivity values, too. Thus, the impact of both lateral and vertical hydraulic conductivity is significant also on groundwater flow. Figure 15B shows the change of surface runoff through time over the study subcatchment (44s), under which the study aquifer lies. As it can be seen from this figure, surface runoff is also affected due to the exchange of water between surface and subsurface.

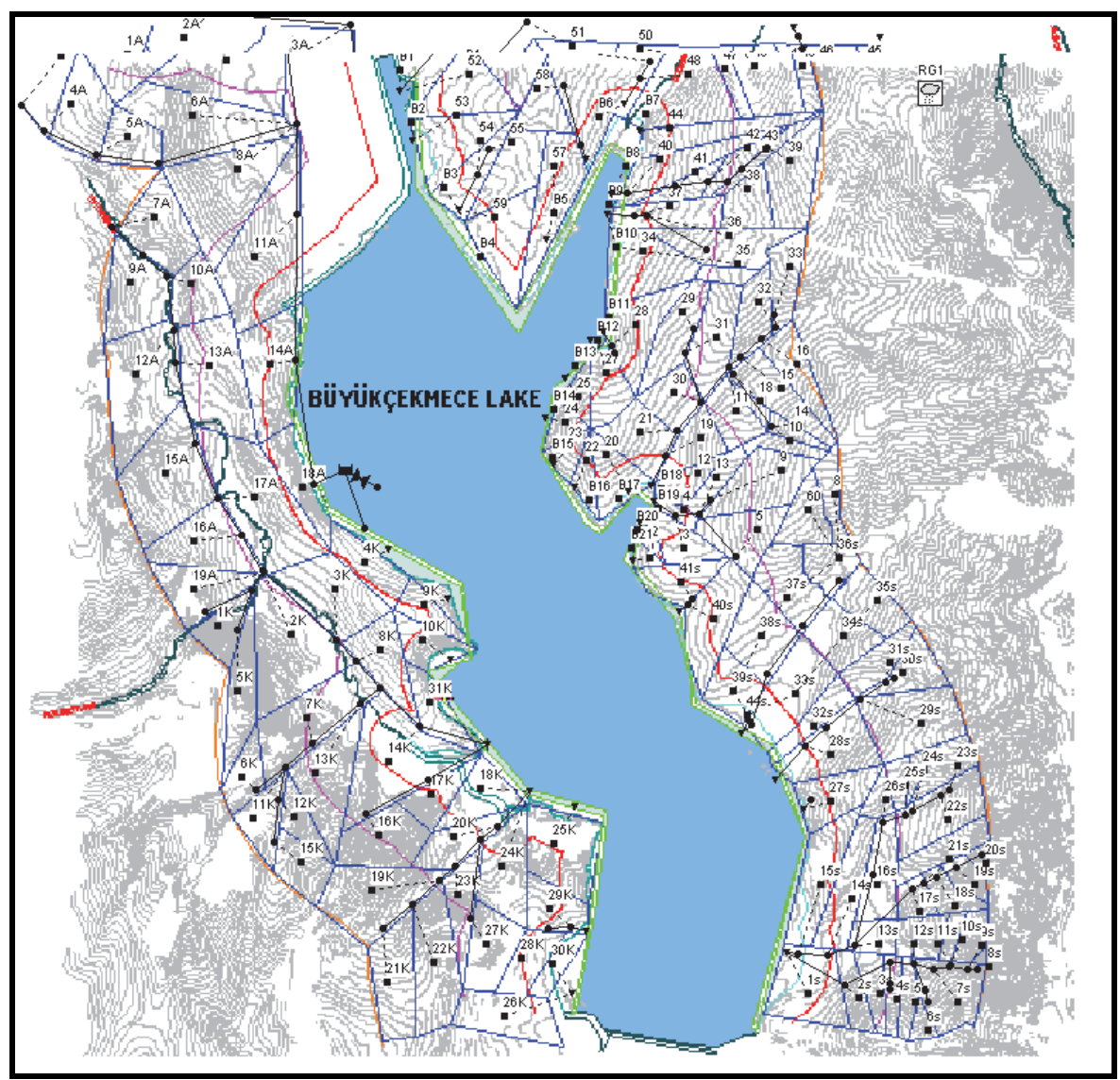

Fig. 13. Hydrological Model of Büyükçekmece wetland site developed by EPA SWMM. Subcatchment borders are shown with blue and conduits are shown with red (not to scale). 


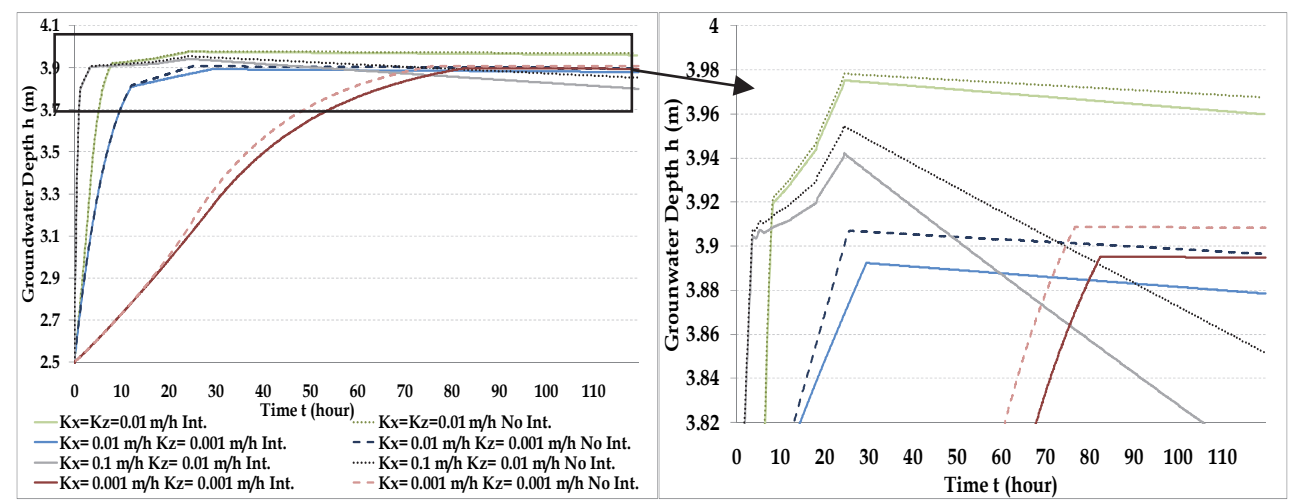

Fig. 14. Comparison of groundwater depth on wetland section 44s with surface and groundwater interaction and with no surface and groundwater interaction.

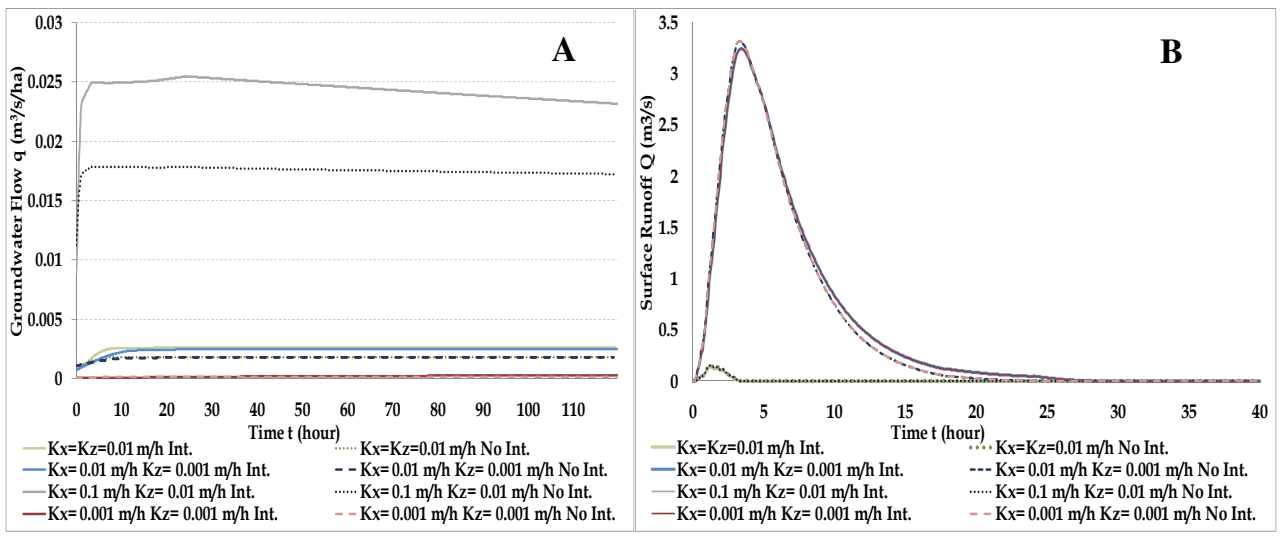

Fig. 15. Comparison of (A) groundwater flow and (B) surface runoff on wetland section 44s with surface and groundwater interaction and with no surface and groundwater interaction.

Figure 16 shows the change of concentration of total nitrogen through time at the outlet of the wetland site which builds up on the catchment during the dry days and is washed off by the surface runoff during a rainfall event. As it can be seen from this figure, the arrival time of the peak concentration to the outlet changes according to different lateral and vertical hydraulic conductivity values. Moreover, we observe different concentration curves for the cases with interaction effect and with no interaction effect. Thus, we conclude that hydraulic conductivity affects both the concentration curve and the arrival time of the peak concentration of the pollutants in the surface runoff significantly. 


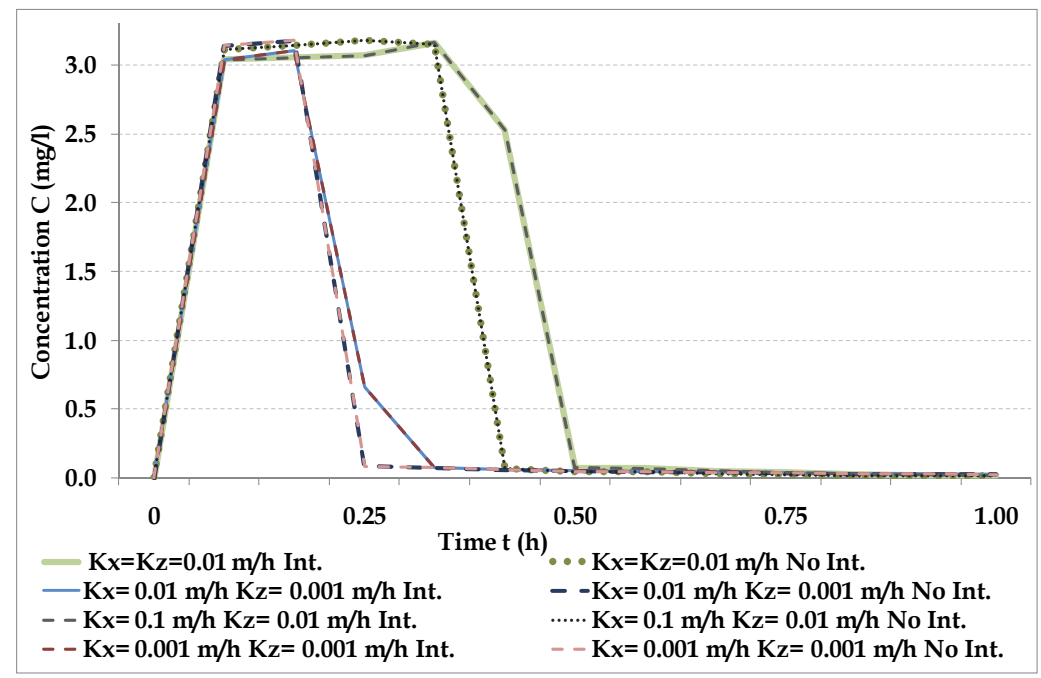

Fig. 16. Comparison of total nitrogen concentration in surface runoff on wetland site with surface and groundwater interaction and with no surface and groundwater interaction.

\section{Conclusion}

Surface and groundwater interactions play a crucial role in the behavior of hydrology and contaminant transport in streams, lakes, and wetlands. Therefore, it is important to take these interactions into account when modeling water resources. In this chapter, wetland hydrology, wetland water quality, and surface and groundwater interactions are presented. Then, several models, which incorporate surface and groundwater interactions in their hydrological and contaminant transport simulations, are illustrated. These models are WETSAND, Visual MODFLOW and EPA SWMM. Particularly, the role of hydraulic conductivity on surface and groundwater interactions in wetlands is investigated in detail by using these models.

An example study is given for each model. Each model presents the influence of surface and groundwater interactions from a different point of view: WETSAND shows the effect of the interactions on surface water depth and surface water contaminant at a wetland site; Visual MODFLOW shows the effect of the interactions on groundwater flow and groundwater contaminant; EPA SWMM shows the effect of interactions on surface runoff, groundwater depth and flow, and wash off of the contaminant on land surface. Thus, each model has a different feature and therefore is used in presenting different aspects and characteristics of surface and groundwater interactions. Simulations are conducted for a conceptual wetlandaquifer system with Visual MODFLOW, the Duke University restored wetland site in the Sandy Creek watershed of Durham, North Carolina in USA with WETSAND and Büyükçekmece wetland site located around Büyükçekmece Lake in Istanbul, Turkey with EPA SWMM. 
The results clearly show that both lateral and vertical hydraulic conductivity influence surface and groundwater interactions. The effects of surface and groundwater interactions play a significant role on wetland dynamics and therefore should be taken into account when modeling wetland hydrology and wetland solute transport.

\section{Acknowledgment}

The author would like to express her gratitude to General Directorate of State Hydraulics Works (DSI), Turkish State Meteorological Service (DMI), Istanbul Metropolitan Municipality (IBB) and Istanbul Municipality Waterworks (ISKI) for providing rainfall data, site map, soil formation, and valuable discussions on the Büyükçekmece wetland site. Rainfall data for Duke University restored wetland site were obtained from a project supported by the Office of Science (BER), U.S. Department of Energy, Grant No. DE-FG0295ER62083. The author wishes to acknowledge also the Facilities Management Department of Duke University for partial funding and valuable discussions on stormwater and wetland hydrologic and water quality modeling needs on Duke University Campus, and the Duke University Wetland Center for providing water level data.

\section{References}

Bencala, K.E. (2000). Hyporheic Zone Hydrological Processes. Hydrological Processes, Vol.14, No.15, pp . 2797-2798.

Birpınar M.E. ; Özkılıç N. ; Aktürk M.A. ; Mumcuoğlu H. ; Pirim S. ; Kurtuluş S. ; Aykırı S. ; Yaman M. ; Vardar A. ; Kuzlu A. ; Çakmak, B. ; Akdağ, B. ; Cihan, F. ; Selvi, G.M. ; Şanlımeşhur, İ. ; Sadıkel, İ. ; Özdoğan, J. ; Karabulut, A. ; Akkaş, S. Ö. ; Bukni, R.; Tezcan, Ş.; Erdoğan, T. \& Karaaslan, Y. (2006). Environmental Report of Istanbul for year 2005, Available from http:/ / www.cedgm.gov.tr.

Choi, J. \& Harvey, J.W. (2000). Quantifying Time-Varying Ground-Water Discharge and Recharge in Wetlands of the Northern Florida Everglades. Wetlands, Vol.20, No.3, pp. 500-511.

Chu, S.T. (1978). Infiltration During an Unsteady Rain. Water Resources Research, Vol.14, No.3, pp. 461-466.

Crowe, A.S.; Shikaze, S.G. \& Ptacek, C.J. (2004). Numerical Modelling of Groundwater Flow and Contaminant Transport to Point Pelee Marsh, Ontario, Canada. Hydrological Processes, Vol.18, No.2, pp. 293-314.

Devito, K.J. \& Hill, A.R. (1997). Sulphate Dynamics in Relation to Groundwater-Surface Water Interactions in Headwater Wetlands of the Southern Canadian Shield. Hydrological Processes, Vol.11, No.5, pp. 485-500.

Eagleson, P.S. (1970). Dynamic Hydrology, McGraw-Hill, Inc.

EarthInfo Inc. (2004). USGS Daily Values East. CO: EarthInfo Inc.

Giraldi, D.; Vitturi, M. de M. \& Iannelli, R. (2010). FITOVERT: A Dynamic Numerical Model of Surbsurface Vertical Flow Constructed Wetlands. Environmental Modelling $\mathcal{E}$ Software, Vol.25, pp. 633-640.

Hakenkamp, C.C.; Valett, H.M. \& Boulton, A.J. (1993). Perspectives on the Hyporheic Zone: Integrating Hydrology and Biology. Concluding Remarks. Journal of the North American Benthological Society, Vol.12, No.1, pp. 94-99. 
Harbaugh A.W. \& McDonald M.G. (1996a). User's Documentation for MODFLOW-96, an Update to the U.S. Geological Survey Modular Finite-Difference Ground-Water Flow model. Open-File Report 96-485, USGS.

Harbaugh A.W. \& McDonald M.G. (1996b). Programmer's Documentation for MODFLOW96 an Update to the U.S. Geological Survey Modular Finite-Difference GroundWater Flow Model", Open-File Report 96-486, USGS.

Harbaugh A.W.; Banta E.R.; Hill M.C. \& McDonald M.G. (2000). MODFLOW-2000, the US Geological Survey Modular Ground-Water Model -- User Guide to Modularization Concepts and the Ground-Water Flow Process", Open-File Report 00-92, USGS.

Harbaugh, A.W. (2005). MODFLOW-2005, the U.S. Geological Survey Modular GroundWater Model -- the Ground-Water Flow Process: U.S. Geological Survey Techniques and Methods. 6-A16, variously p.

Harvey, J.W.; Newlin, J.T. \& Krupa, S.L. (2006). Modeling Decadal Timescale Interactions Between Surface Water and Ground Water in the Central Everglades, Florida, USA. Journal of Hydrology, Vol.320, pp. 400-420.

He, Z.; Wu, W. \& Wang, S.S.Y. (2010). Coupled Finite-Volume Model for 2D Surface and 3D Subsurface Flows. Journal of Hydrologic Engineering, ASCE, Vol.13, No.9, pp. 835845.

Herron, N. \& Croke, B. (2009). Including the Influence of Groundwater Exchanges in a Lumped Rainfall-Runoff Model. Mathematics and Computers in Simulation, Vol. 79, pp. 2689-2700.

Huber, W.C. \& Dickinson, R.E. (1988). Storm Water Management Model, Version 4, User's Manual, Athens, GA.: Environmental Research Laboratory, Office of Research and Development, U.S. Environmental Protection Agency (EPA).

Kadlec, R.H. (1990). Overland Flow in Wetlands: Vegetation Resistance. Journal of Hydraulic Engineering, ASCE, Vol.116, No.5, pp. 691-706.

Kadlec, R.H. \& Knight, R.L. (1996). Treatment Wetlands, CRC Press, Inc.

Kazezyılmaz-Alhan, C. M. \& Medina, M. A. Jr. (2008). The Effect of Surface/Ground Water Interactions on Wetland Sites with Different Characteristics. Desalination, Vol.226, pp. 298-305.

Kazezyılmaz-Alhan, C. M., Medina, M. A. Jr. \& Richardson, C. (2007). A Wetland Hydrology and Water Quality Model Incorporating Surface Water/Groundwater Interactions. Water Resources Research, Vol.43, No.4, W04434, pp. 1-16.

Keefe, S.H.; Barver, L.B.; Runkel, R.L.; Ryan, J.N.; McKnight D.M. \& Wass, R.D. (2004). Conservative and Reactive Solute Transport in Constructed Wetlands. Water Resources Research, Vol.40, No.1, W01201.

Krasnostein, A.L. \& Oldham, C.E. (2004). Predicting Wetland Water Storage. Water Resources Research, Vol.40, No.10, W10203.

Lighthill, M.J. \& Whitham, G.B. (1955). On Kinematic Waves. I. Flood Movement in Long Rivers. Proceedings, Royal Society of London, London, England, Series A, Vol.229, No.1178, pp. 281-316.

McDonald, M.G. \& Harbaugh, A.W. (1988). A Modular Three-Dimensional Finite Difference Groundwater Flow Model. Techniques of Water-Resources Investigations, Book 6, Chap A1, U.S. Geological Survey. 
McHale, M.R.; Cirmo, C.P.; Mitchell, M.J. \& McDonnell, J.J. (2004). Wetland Nitrogen Dynamics in an Adirondack Forested Watershed. Hydrological Processes, Vol.18, No.10, pp. 1853-1870.

Medina, M.A.; Doneker, R.L.; Grosso, N.; Johns, D.M.; Lung, W.; Mohsen, M.F.N.; Packman, A.I. \& Roberts, P.J. (2002). Chapter 1: Surface Water-Ground Water Interactions and Modeling Applications, In: Environmental Modeling and Management: Theory, Practice and Future Directions, Chien, C.C.; Medina, M.A. Jr.; Pinder, G.F; Reible, D.R.; Sleep, B.E. \& Zheng, C., (Eds.), Published by Today Media, Inc. for the DuPont Company, Wilmington, pp. 1-62.

Min, J.-H. \& Wise, W.R. (2010). Depth-Averaged, Spatially Distributed Flow Dynamic and Solute Transport Modeling of a Large-Scaled, Subtropical Constructed Wetland. Hydrological Processes, Vol.24, pp. 2724-2737.

Mitchell G.F.; Hunt, C.L. \& Su, Y.M. (2002). Mitigating Highway Runoff Constituents via a Wetland. Soil Mechanics 2002 Transportation Research Record, Vol.1808, pp. 127133.

Mitsch, W.J. \& Gosselink, J.G. (2000). Wetlands, Third Edition, John Wiley, New York.

Moore, M.T.; Schulz, R.; Cooper, C.M. \& Rodgers, J.H. (2002). Mitigation of Chlorpyrifos Runoff Using Constructed Wetlands. Chemosphere, Vol.46, No.6, pp. 827-835.

Packman, A.I. \& Bencala, K.E. (2000). Modeling Surface-Subsurface Hydrologic Interactions, In: Streams and Ground Waters, Jones, J.B. \& Mulholland, P.J. (Eds.), Academic Press, San Diego, CA, pp. 45-80.

Ponce, V.M. (1989). Engineering Hydrology: Principles and Practices. Prentice Hall, Inc, Englewood Cliffs, New Jersey 07632.

Ponce, V.M. \& Hawkins, R.H. (1996). Runoff Curve Number: Has It Reached Maturity? Journal of Hydrologic Engineering-ASCE, Vol 1, No.1, pp:11-19.

Price, J.S. \& Wadington, J.M. (2000). Advances in Canadian Wetland Hydrology and Biochemistry. Hydrological Processes, Vol.14, No.9, pp. 1579-1589.

Restrepo, J.I.; Montoya, A.M. \& Obeysekera, J. (1998). A Wetland Simulation Module for the MODFLOW Ground Water Model. Ground Water, Vol.36, No.5, pp. 764-770.

Rossman, L.A. (2010). Storm Water Management Model, User's Manual, Version 5. Water Supply and Water Resources Division National Risk Management Research Laboratory, Cincinnati, OH, U.S. Environmental Protection Agency, EPA/600/R-05/040.

Schlumberger Water Services. (2009). Visual MODFLOW 2009.1 User's Manual. For Professional Applications in Three-Dimensional Groundwater Flow and Contaminant Transport Modeling.

Thornthwaite, C.W. (1948). An Approach Toward a Rational Classification of Climate. Am. Geogr. Rev., Vol.38, pp. 55-94.

Winter, T.C. (1995). Recent Advances in Understanding the Interaction of Groundwater and Surface water. Reviews of Geophysics, Supplement, pp. 985-994.

Winter, T.C. \& Rosenberry, D.O. (1995). The Interaction of Ground Water with Prairie Pathole Wetlands in the Cottonwood Lake Area, East-Central North Dakota, 19791990. Wetlands, Vol.15, No.3, pp. 193-211.

Winter, T.C.; Harvey, J.W.; Franke, O.L. \& Alley, W.M. (1998). Ground Water and Surface Water A Single Resource. U.S. Geological Survey Circular 1139. 
Winter, T.C. (1999). Relation of Streams, Lakes, and Wetlands to Groundwater Flow Systems. Hydrogeology Journal, Vol. 7, pp. 28-45.

Zheng, C. (1990). MT3D, A Modular Three-Dimensional Transport Model for Simulation of Advection, Dispersion and Chemical Reactions of Contaminants in Groundwater Systems. Report to the U.S. Environmental Protection Agency, Robert S. Kerr Environmental Research Laboratory, Ada, OK. 


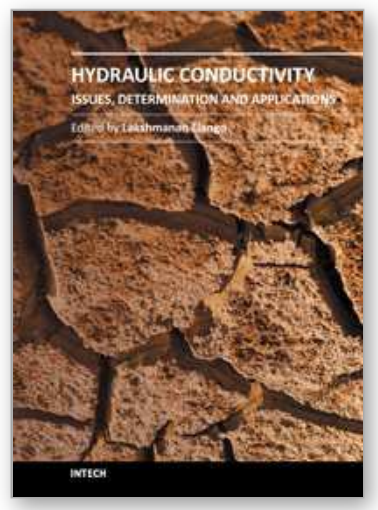

\author{
Hydraulic Conductivity - Issues, Determination and Applications \\ Edited by Prof. Lakshmanan Elango
}

ISBN 978-953-307-288-3

Hard cover, 434 pages

Publisher InTech

Published online 23, November, 2011

Published in print edition November, 2011

There are several books on broad aspects of hydrogeology, groundwater hydrology and geohydrology, which do not discuss in detail on the intrigues of hydraulic conductivity elaborately. However, this book on Hydraulic Conductivity presents comprehensive reviews of new measurements and numerical techniques for estimating hydraulic conductivity. This is achieved by the chapters written by various experts in this field of research into a number of clustered themes covering different aspects of hydraulic conductivity. The sections in the book are: Hydraulic conductivity and its importance, Hydraulic conductivity and plant systems, Determination by mathematical and laboratory methods, Determination by field techniques and Modelling and hydraulic conductivity. Each of these sections of the book includes chapters highlighting the salient aspects and most of these chapters explain the facts with the help of some case studies. Thus this book has a good mix of chapters dealing with various and vital aspects of hydraulic conductivity from various authors of different countries.

\title{
How to reference
}

In order to correctly reference this scholarly work, feel free to copy and paste the following:

Cevza Melek Kazezyılmaz-Alhan (2011). Role of Hydraulic Conductivity on Surface and Groundwater Interaction in Wetlands, Hydraulic Conductivity - Issues, Determination and Applications, Prof. Lakshmanan Elango (Ed.), ISBN: 978-953-307-288-3, InTech, Available from: http://www.intechopen.com/books/hydraulicconductivity-issues-determination-and-applications/role-of-hydraulic-conductivity-on-surface-and-groundwaterinteraction-in-wetlands

\section{INTECH}

open science | open minds

\section{InTech Europe}

University Campus STeP Ri

Slavka Krautzeka 83/A

51000 Rijeka, Croatia

Phone: +385 (51) 770447

Fax: +385 (51) 686166

www.intechopen.com

\section{InTech China}

Unit 405, Office Block, Hotel Equatorial Shanghai

No.65, Yan An Road (West), Shanghai, 200040, China

中国上海市延安西路65号上海国际贵都大饭店办公楼 405 单元

Phone: +86-21-62489820

Fax: $+86-21-62489821$ 
(C) 2011 The Author(s). Licensee IntechOpen. This is an open access article distributed under the terms of the Creative Commons Attribution 3.0 License, which permits unrestricted use, distribution, and reproduction in any medium, provided the original work is properly cited. 